University of Nebraska - Lincoln

DigitalCommons@University of Nebraska - Lincoln

Industrial and Management Systems

Industrial and Management Systems

Engineering Faculty Publications

Engineering

1999

\title{
Models in Manual Materials Handling
}

M. M. Ayoub

Texas Tech University

Jeffrey C. Woldstad

University of Nebraska - Lincoln, Jeffrey.Woldstad@sdsmt.edu

Follow this and additional works at: https://digitalcommons.unl.edu/imsefacpub

Part of the Operations Research, Systems Engineering and Industrial Engineering Commons

Ayoub, M. M. and Woldstad, Jeffrey C., "Models in Manual Materials Handling" (1999). Industrial and Management Systems Engineering Faculty Publications. 14.

https://digitalcommons.unl.edu/imsefacpub/14

This Article is brought to you for free and open access by the Industrial and Management Systems Engineering at DigitalCommons@University of Nebraska - Lincoln. It has been accepted for inclusion in Industrial and Management Systems Engineering Faculty Publications by an authorized administrator of DigitalCommons@University of Nebraska - Lincoln. 


\title{
Models in Manual Materials Handling
}

\author{
M. M. Ayoub and Jeffrey C. Woldstad
}

\section{INTRODUCTION}

The ergonomics approach to manual materials handling $(\mathrm{MMH})$ tasks defines a ManTask-Environment System. A generally accepted means of minimizing MMH related injuries is to design MMH tasks so that the demands of the tasks are less than the capacities of the individuals performing these tasks. Task design is dependent, in part, on the availability of comparable data for task demands and worker capacities. The generation of the appropriate data is dependent, in part, on being able to identify the pertinent capacity parameters of manual materials handling activities.

In the past, a substantial effort has been directed at determining 'safe' lifting capacities for individuals and groups of individuals. The assumption used for these studies was that there is a relationship between an individual's capacity and his or her injury potential. In other words, a person with a small capacity with respect to a given task demand is more likely to be injured than another person with larger capacities. For the measurement of a safe and permissible lifting capacity three approaches are commonly used. The first approach is the biomechanical approach, the second approach is the physiological approach, and the third is the psychophysical approach. These three approaches and the models developed using the selected criterion under each approach are discussed below.

\section{THE BIOMECHANICAL APPROACH}

Using the biomechanical approach, researchers attempt to model directly the mechanical stresses placed upon the internal structures of the body during lifting. The goal of this approach is to accurately estimate how work activities stress the bones, muscles and connective tissues of the body and to predict when these stresses will lead to damage of these structures. This approach is very popular in ergonomics because it closely corresponds with most expert views of the aetiology of injury during manual materials handling (NIOSH, 1981). 
Biomechanical models typically model the human body as a series of mechanical links and joints corresponding to the human skeleton. Both external forces, needed to perform the work activity, and internal forces, as a result of muscle contraction, are modeled to estimate the mechanical stresses. Most models focus on estimating only a few mechanical stress parameters related to the injury of interest in the analysis. For manual materials handling the parameter most often selected is the compressive force on the low back, usually the L5/S1 spine segment.

\section{The criterion selected}

The criterion selected in most biomechanical analyses of manual materials handling has been greatly influenced by the National Institute for Occupational Safety and Health's (NIOSH) guidelines for Manual Lifting (NIOSH, 1981, 1994). In developing a biomechanical criterion, NIOSH arrived at the following three conclusions based upon a review of the literature (NIOSH, 1994):

(1) The joint between L5 (fifth lumbar) and S1 (first sacral) is the joint of greatest lumbar stress during lifting.

(2) Compressive force (at this joint) is the critical stress vector.

(3) The compressive force criterion that defines increased risk is $3.4 \mathrm{kN}$.

Support for these assumptions can be found in both NIOSH documents (NIOSH, 1981, 1994) and in epidemiological studies by Herrin et al. (1986), Bringham and Garg (1983), Anderson (1983), and Chaffin and Park (1973). However recent work by Leamon (1994) suggests that more research is needed in this area.

Several other criteria have been used to a lesser extent in biomechanical modeling, including the external hip moment, the external moment at L5/S1 joint, anterior-posterior (A-P) shear force, and lateral shear force. In addition, Man-as et al. (1993) have recently proposed using kinematic parameters of the torso as criterion to predict injury (Marras et al., 1993, 1995). Because most models attempt to predict compressive force, A-P shear force, and lateral shear force at the lower back (either L5/S1 or L3/L4), the rest of this section will focus on these criteria.

\section{Estimating the external load moment}

All biomechanical models employed to evaluate lifting begin by knowing the external load placed on the body by the task under study. The procedure used for this calculation in different models is essentially the same, with slight differences in the kinematic representations of the body and the anthropometric and body segment data that are used in the calculation. The skeleton of the body is modeled as a series of rigid links or levers connected at frictionless pin joints. With several other assumptions, engineering mechanics is used to calculate the moment created by the force acting at the hands at each joint, beginning with joints closest to the hands and ending at the joint of interest (usually the L5/S1 or L4/L5 intervertebral joints). Implicit in the construction of these models are simplify- 
ing assumptions regarding the number and geometric complexity of the joints and bones of the human body.

Biomechanical models are either two-dimensional or three-dimensional and either static or dynamic. For static models, the calculations require information on the orientation of the links in the model (subject's posture), the length of each segment, the mass of each segment, and the location of the center-of-mass of each segment. Dynamic models require this same information plus the angular joint accelerations, linear acceleration of each segment at the center-of-mass, and the moment-of-inertia of each link through the center of mass. A general equation to calculate the static moment at successive joints in a linkage is:

$$
\underline{M}_{\text {joint }}=\underline{M}_{\text {joint }-1}+\left(\underline{L}_{\text {link }} \times \underline{F}_{\text {joint }-1}\right)+\left(\underline{C M}_{\text {link }} \times m_{\text {link }} \underline{G}\right)
$$

where:

$\underline{M}_{\text {joint }}$ is the reactive load moment vector for the joint of interest,

$\underline{M}_{\text {joint }-1}$ is the reactive load moment vector for the joint previous to the joint of interest in the linkage,

$\underline{L}_{\text {link }}$ is the vector from the position of the joint of interest to the previous joint,

$\underline{F}_{\text {joint }-1}$ is the reactive force for the joint previous to the joint of interest,

$\underline{C M_{\text {link }}}$ is the vector from the position of the joint of interest to the center-of-mass position for that link,

$m_{\text {link }}$ is the mass of the link, and

$\underline{G}$ is the vector representing acceleration due to gravity.

For dynamic models, an equivalent equation is:

$\underline{M}_{\text {joint }}=\underline{M}_{\text {joint }-1}+\left(\underline{L}_{\text {link }} \times \underline{F}_{\text {joint }-1}\right)+\left(\underline{C M}_{\text {link }} \times m_{\text {link }} \underline{G}\right)+\left(\underline{C M}_{\text {link }} \times m_{\text {link }} \underline{A}_{\text {link }}\right)+\left(\underline{\theta}_{\text {joint }} \times \underline{I}_{\text {link }}\right)$

where:

$\underline{M}_{\text {joint }}$ is the reactive load moment vector for the joint of interest,

$\underline{M}_{\text {joint }-1}$ is the reactive load moment vector for the joint previous to the joint of interest in the linkage,

$\underline{L}_{\text {link }}$ is the vector from the position of the joint of interest to the previous joint,

$\underline{F}_{\text {joint }-1}$ is the reactive force for the joint previous to the joint of interest,

$\underline{C M}_{\text {link }}$ is the vector from the position of the joint of interest to the center-of-mass position for that link,

$m_{\text {link }}$ is the mass of the link,

$\underline{G}$ is the vector representing acceleration due to gravity,

$\underline{A}_{\text {link }}$ is the instantaneous linear acceleration vector of the link center-of-mass,

$\underline{\ddot{\theta}}_{\text {joint }}$ is the angular acceleration of the link about the joint of interest, and

$\underline{I}_{\text {link }}$ is the moment-of-inertia of the link through the center-of-mass.

Anthropometric data needed for these equations can be found in a number of sources including Dempster (1955), Clauser et al. (1969) and NASA (1978). Additional details on how to calculate external load moments can be found in Chaffin and Andersson (1991), Winter (1990), Ozkaya and Nordin (1991) and Williams and Lissner (1977). 


\section{Estimating internal muscle forces}

The forces acting on the intervertebral discs are a combination of the external forces at the joints and the internal forces created by muscles and connective tissues. For two-dimensional models, muscle forces are usually estimated by assuming that the erector spinae muscle acts to generate force if the external load moment at the torso is acting to increase torso flexion (i.e., lifting activities) and the rectus abdominus muscle is active if the external load moment at the torso is acting to decrease torso flexion (i.e. pushing down). For static models, the muscle forces can be derived using the conditions of static equilibrium. For dynamic activities, Newton's second law can be used. The most popular twodimensional static biomechanical model currently in use is the University of Michigan's 2D Static Strength Prediction Program. In addition to using the erector spinae muscles and the rectus abdominus muscles, this model also adds internal forces due to the interabdominal pressure (IAP) created by the muscles of the torso during lifting activities. The use of interabdominal pressure in biomechanical models has been questioned by several researchers (Mairiaux and Malchaire, 1988; McGill and Norman, 1986) and is not generally included in most three-dimensional models. In addition to disc compressive forces, the University of Michigan's 2D Static Strength Prediction Program also predicts muscle strength at each joint included in the model.

Estimating internal muscle forces has proven to be difficult for three-dimensional models due to the complexity of the human torso. Because the number of muscles in the torso region is generally greater than the number of force and moment equations, the problem is indeterminate. Optimization procedures were first employed to solve for the static three-dimensional muscle forces in the torso by Schultz et al. (1983). This model was later refined into the minimum-intensity-compression (MIC) model (Bean et al., 1988). The model employs a two-step linear programming approach to estimating the internal muscle forces. The first step in the procedure:

\section{Minimize $I$}

subject to:

$$
\begin{aligned}
& \sum_{i=1}^{m}\left\|f_{i}\right\|\left(\underline{r}_{i} \times \underline{\tau}_{i}\right)+\underline{M}_{j o i n t}, \\
& \frac{f_{i}}{A_{i}} \leq I, \\
& f_{i} \geq 0,
\end{aligned}
$$

where:

$f_{i}$ is the tension in each muscle,

$\underline{r}_{i}$ is the moment arm vector,

$\underline{\underline{I}}_{i}$ is the muscle line-of-action vector,

$\underline{M}_{\text {joint }}$ is the reactive load moment for the joint of interest,

finds the minimum - maximum muscle intensity for the muscles being considered in the model. Intensity is defined as the force exerted by the muscle divided by the cross-sectional area of the muscle. The second step in the procedure:

$$
\text { Minimize }\left\|f_{i}\right\|_{\underline{I}_{i}^{z}}^{z}
$$


subject to:

$$
\begin{aligned}
& \sum_{i=1}^{m}\left\|f_{i}\right\|\left(\underline{r}_{i} \times \tau_{i}\right)+\underline{M}_{j o i n t}, \\
& \frac{f_{i}}{A_{i}} \leq I^{*}, \\
& f_{i} \geq 0,
\end{aligned}
$$

where:

$f_{i}$ is the tension in each muscle,

$\underline{r}_{i}$ is the moment arm vector,

$\underline{\tau}_{i}$ is the muscle line-of-action vector,

$\underline{M}_{\text {joint }}$ is the reactive load moment for the joint of interest,

$I^{*}$ is the minimum intensity value from the first step in the procedure,

selects muscle forces which satisfy the minimum intensity criteria generated in the first step and also minimizes the compressive force on the intervertebral disc. The second step is only needed if multiple optima are found in the first step which seldom occurs in practical application of the model. This model is included in the University of Michigan's 3D Static Strength Prediction Program. The main output screens of this computer program for a typical lifting task are shown in Figure 1.

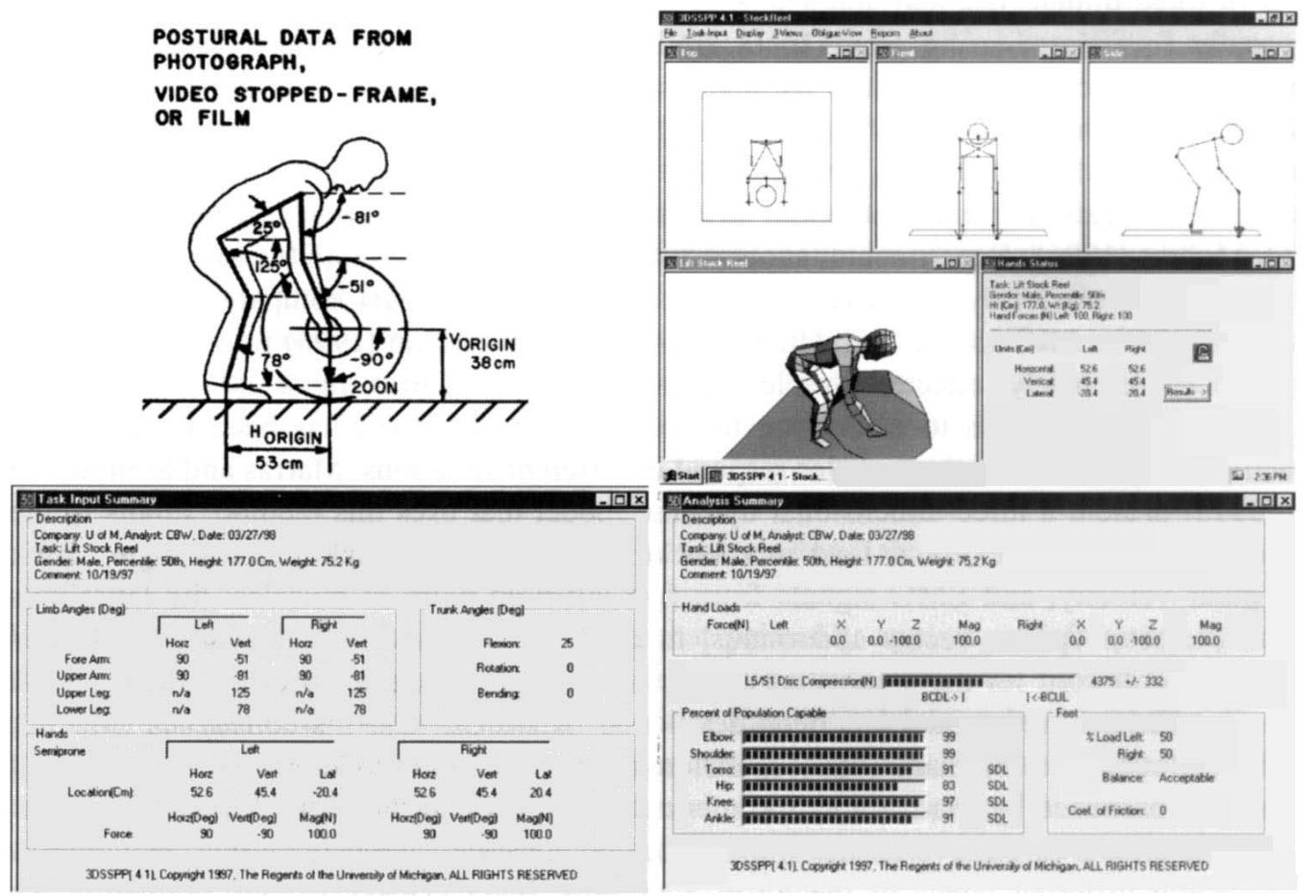

Figure 1. Work task and main output screens for the University of Michigan's 3D Static Strength Prediction Program (reprinted with permission from the University of Michigan, 1998). 
A second optimization model often used to estimate static muscle force in the torso is the sum of cubed intensities (SCI) model first proposed for use in modeling the extremities by Crowminshield and Brand (1981). While similar to the MIC model, this algorithm employs non-linear programming which makes the solution procedure, in general, more difficult. The SCI optimization model is formulated as:

Minimize $\quad \sum_{i=1}^{m}\left(\frac{f_{i}}{A_{i}}\right)^{3}$

subject to:

$$
\sum_{i=1}^{m}\left\|f_{i}\right\|\left(\underline{r}_{i} \times \tau_{i}\right)+\underline{M}_{j o i n t},
$$

$$
f_{i} \geq 0,
$$

where:

$f_{i}$ is the tension in each muscle,

$\underline{r}_{i}$ is the moment arm vector,

$\underline{I}_{i}$ is the muscle line-of-action vector,

$\underline{M}_{\text {joint }}$ is the reactive load moment for the joint of interest,

Both the MIC and the SCI optimization procedures do not restrict the number of muscle forces predicted, but they require information on the cross-sectional area of the muscles, the muscle line of action, and the muscle moment arm vector. This information must be in three dimensions and applicable to the joint of interest in the model. Models are usually formulated using from 10 to 22 different muscles about the torso. Relevant anthropometric values for these parameters can be found a variety of sources (Chaffin et al., 1990; Dumas et al., 1988; Han et al., 1992; Macintosh and Bogduk, 1986; McGill et al., 1988; Schultz et al., 1983; Tracy et al., 1989). A review of different torso anthropometries and their potential effects on optimization models can be found in McMulkin (1996). Experimental support using electromyographs (EMGs) was provided for the MIC model by Ladin et al. (1989); however, in a direct comparison of the SCI model and the MIC model, both Hughes (1991) and McMulkin (1996) found that the SCI model more closely reflected muscle activation patterns of torso muscles.

A second approach to estimating the internal muscle forces has been to use EMG activity to predict how the muscles respond in different situations. Marras and Sommerich (1991a) present a three-dimensional dynamic model that uses this method. Inputs to the model include the external load moment at the trunk, the trunk flexion angle, trunk angular velocity, and EMG signals from five left/right pairs of muscles: the latissimus dorsi, erector spinae, rectus abdominus, internal oblique, and external oblique. EMGs must be collected for the activity of interest and for maximum exertions of the trunk. A similar EMG based model has been developed by McGill and his colleagues (McGill, 1992; McGill and Norman, 1986). A difference between the model proposed by McGill and that proposed by Marras and Sommerich (1991a) is that the McGill model incorporates the effects of passive tissues into the calculations and it considers muscle activities at several different levels of the torso. Kee and Chung (1996) recently compared the predictions of the Marras and Sommerich (1991a) biomechanical model to those of the MIC model. The MIC model was applied to a dynamic lifting situation by sequentially applying the model 
at consecutive time intervals throughout the lift. The results of this comparison demonstrated substantial differences between the predictions of the two models, especially for asymmetric tasks.

A third class of biomechanical model has recently been proposed which incorporates both optimization and EMG components to estimate internal muscle forces. Nussbaum and Chaffin (1996) recently proposed an artificial neural network model that uses EMG signals as a learning tool. The model takes as input the external load moment at the torso and produces as output muscle activities for four left/right pairs of muscles: the latissimus dorsi, erector spinae, rectus abdominus, and external oblique. A quantitative evaluation of the model performed by Nussbaum and Chaffin (1996) indicates remarkable agreement with measured EMG signals. Cholewicki and McGill (1996) have also developed a model that employs both EMG and optimization techniques. This model estimates muscle forces using EMG signals as inputs and then adjusts to force using an optimization routine.

\section{The effect of task variables on model predictions}

Biomechanical models have been used to evaluate the effects of many different task variables on workers performing manual materials handling tasks. Most biomechanical models are very sensitive to the magnitude of the load and position of the load in relation to the position of the torso. Increasing the load, moving the load away from the body, and moving the load down from waist level to the floor substantially increases the L5/S1 compressive force as shown in Figure 2. These estimates were produced using a two-dimensional static model similar to the University of Michigan's 2D Static Strength Prediction Program.

Static biomechanical models have been reported to under-estimate the forces associated with dynamic activities (Freivalds et al., 1984; Garg et al., 1982; Kim, 1990; Leskinen et al., 1983; Man-as and Sommerich, 1991b; McGill and Norman, 1986). The peak compressive force during a dynamic lift activity usually occurs as the load is being accelerated during the motion. For activities with relatively large accelerations, the static estimate of the compressive force at this point is 30-40 per cent lower than the dynamic estimate (Granata and Marras, 1996). Three-dimensional biomechanical models have also shown that asymmetric lift activities result in higher compressive force than symmetric lifts. This occurs for two handed lifts with a twisted body posture (Chen, 1988; Marras and Sommerich, 1991b; Mital and Kromodihardjo, 1986), one handed lifts (Davis et al., 1997), and for team lifts with asymmetric body postures (Marras et al., 1997).

\section{PHYSIOLOGICAL DESIGN APPROACH}

Unlike the biomechanical design approach that primarily applies to infrequent lifting, the physiological approach is applicable to repetitive lifting where the load is within the physical strength of the worker. During repetitive handling tasks, a person's endurance is primarily limited by the capacity of the oxygen transport system. As muscles contract and relax, their increased metabolic energy demand requires an increase in the delivery of oxygen and nutrients to the tissues. If this demand for increased oxygen and nutrients cannot be met, the activity cannot be sustained for long.

When a person is engaged in physical work, such as MMH activities, several physiological responses are affected. These include metabolic energy cost, heart rate, blood pres- 


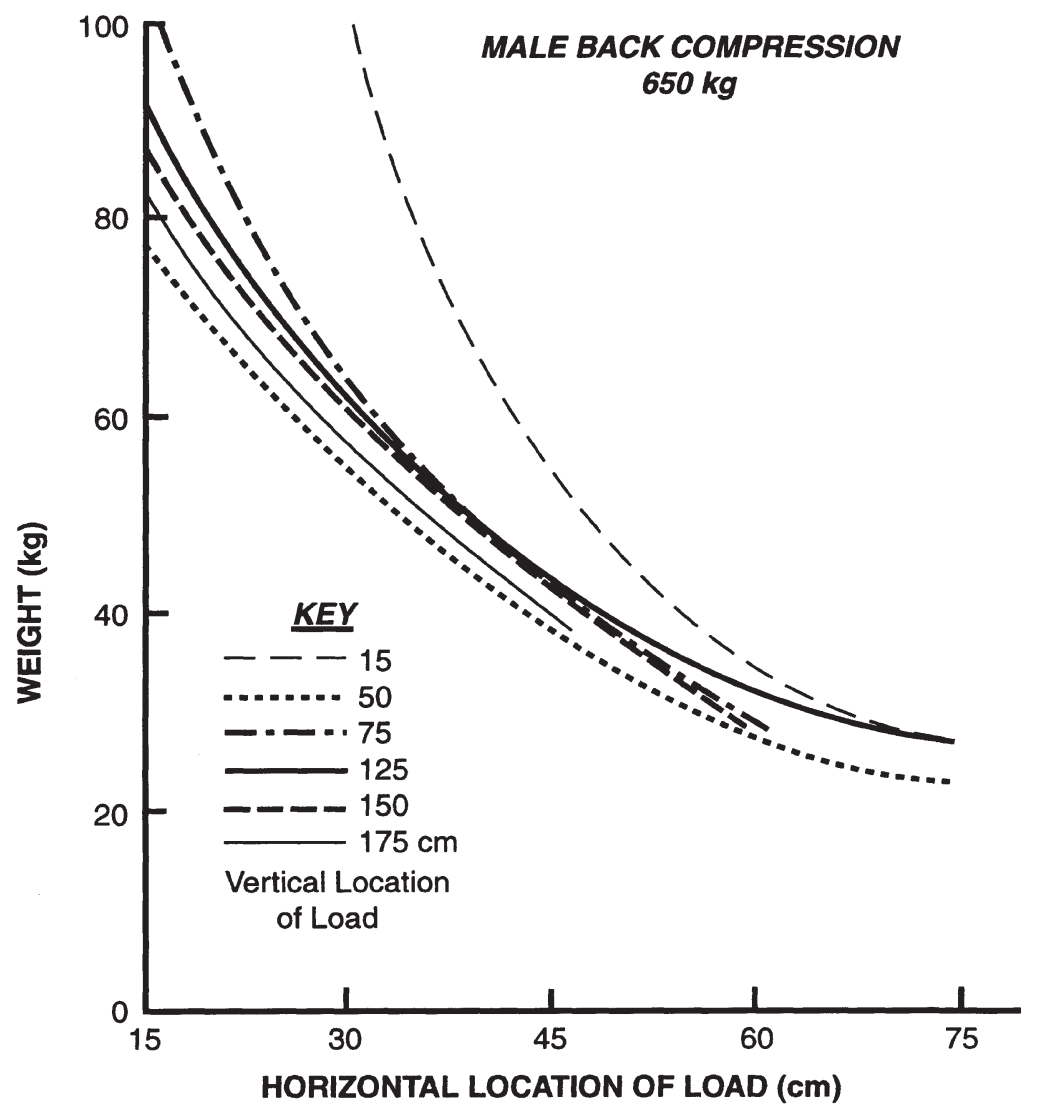

Figure 2. Relationship between the load weight, the horizontal distance away from the spine, and the vertical distance of the load from the floor for a constant $650 \mathrm{~kg}$ L5/S1 compressive force (from NIOSH, 1981).

sure, blood lactate, and ventilation volume. Of all these responses, metabolic energy expenditure has been the widely accepted physiological response to repetitive handling as it is directly proportional to the workload at steady-state conditions (Aquilano, 1968; Astrand and Rodahl, 1986; Ayoub et al., 1981; Durnin and Passmore, 1967; Hamilton and Chase, 1969; Mital, 1984). For this reason, this discussion will exclusively focus on metabolic energy expenditure rate as the physiological approach design criterion.

Several work- and workplace-related factors affect metabolic energy expenditure rate. Table 1 summarizes these factors and their net effect on oxygen consumption. For a detailed discussion on the effect of these and personal factors on oxygen consumption the reader is referred to Manual Materials Handling by Ayoub and Mital (1989).

There is a need for models that can predict the physiological cost (e.g., oxygen consumption and heart rate) of individuals engaged in repetitive manual materials handling $(\mathrm{MMH})$ tasks. Physiological cost models are used in industry to: determine whether or not the task is within the expected capability of the population; and determine the work/ rest schedule for a given task (Asfour, 1980). The literature on physiological cost prediction models for MMH tasks grew in the 1980s. This section will review the existing energy and cardiac cost prediction models for several manual materials handling activities. This by no means is an exhaustive review. 
Table 1. Net effect of work and workplace factors on metabolic energy.

\begin{tabular}{lll}
\hline Factor & & \\
\hline $\begin{array}{l}\text { Frequency of handling }(\uparrow) \\
\text { Task duration }(\uparrow)\end{array}$ & All & Increase \\
decrease $^{\mathrm{b}}$ & All & Increase $^{\mathrm{a}} /$ \\
Object size $(\uparrow)$ & All & \\
Couplings (good) & All & Increase \\
Object shape (various) & All & Decrease \\
Object weight/force $(\uparrow)$ & All & Unknown \\
Load stability/distribution & Lifting, carrying & Increase \\
Vertical height $(\uparrow)$ & Lifting, lowering & Unknown \\
Distance travelled $(\uparrow)$ & Pushing, pulling, carrying & Increase \\
Speed/grade $(\uparrow)$ & Pushing, pulling, carrying & Increase \\
Asymmetrical handling & Lifting & None \\
\hline
\end{tabular}

(From Mital et al., 1997).

$\uparrow$ increase; ${ }^{a}$ if the weight/force does not change; ${ }^{b}$ if the weight/force decreases (e.g., when using the psychophysical methodology).

\section{Energy and cardiac cost for lifting/lowering models}

Several researchers have developed prediction models for the energy and cardiac cost responses of individuals engaged in repetitive manual materials handling tasks. Research in this area has been carried out by Aberg et al. (1968), Asfour (1980), Chaffin (1967), Frederick (1959), Garg (1976), Karwowski and Ayoub (1984a), Liou and Morrissey (1985), Mital (1983b, 1985), Mital et al. (1984) and Morrissey and Liou (1984a, 1984b, 1984c). A list of several energy cost and cardiac cost models is given in Tables 2 and 3 . The cardiac cost models are summarized in Table 4.

Frederick (1959) developed a model to predict the consumption of energy for various weights in four different ranges. Chaffin's model (1967) was developed for static weightholding activities in the sagittal plane. Aberg et al. (1968) developed a model based on the principle that mechanical work is related to a change of the positional energy of mass and frictional losses. Garg (1976) and Garg et al. (1978) used step-wise regression analysis to develop models for lifting, lowering, and carrying activities. Ayoub et al. (1980) provided a review of the energy cost models for manual lifting tasks developed by Aberg et al. (1968), Chaffin (1967), Frederick (1959) and Garg (1976).

Asfour (1980) developed and tested energy cost prediction models for manual lifting and lowering using stepwise regression models, and attempted to overcome some of the limitations cited by Ayoub et al. (1980) by studying the effect of task variables and their interactions on lifting and lowering tasks. The estimated energy expenditure for 512 tasks was based on frequency of lift or lower $(3,6,9$ times/min), load lifted or lower $(6.8,13.6$, $20.4 \mathrm{~kg}$ ), range of height (floor-76 cm, 76-127 cm, floor-127 cm), box width $(38,66 \mathrm{~cm})$, box length $(38,66 \mathrm{~cm})$, and angle of twist of the body (0, 90 degrees). The models developed were reported later by Asfour et al. (1985).

Karwowski and Ayoub (1984a) developed a model to estimate the oxygen consumption associated with the maximum weight (MAW) of lift, determined psychophysically, for frequencies of $0.1,3,9$, and 12 lifts/min when lifting from floor to table height $(76 \mathrm{~cm})$. The inputs to the model are the frequency of lift, maximum acceptable load weight, body weight, and age. This model is presented in Table 2. 
Table 2. Energy cost prediction models for lifting tasks.

\begin{tabular}{|c|c|c|c|}
\hline Source & Dependent variable & Type of task & Model \\
\hline Frederick (1959) & $\begin{array}{l}\text { Total energy } \\
\text { expenditure per hour }\end{array}$ & $\begin{array}{l}\text { Lifting from floor to } \\
20 \text { in, } 20 \text { in to } 40 \text { in, } \\
40 \text { in to } 60 \text { in and } 60 \\
\text { in to } 80 \text { in }\end{array}$ & $\begin{array}{l}\text { TEE }=(\text { Number of lifts } / \\
\text { hour })^{*}(\text { lifting height in } \\
\text { feet })^{*} \text { (weight of load } \\
\text { in pounds) }{ }^{*} \text { (energy } \\
\text { consumption in gm cal/foot } \\
\text { pound)/1000 }\end{array}$ \\
\hline Garg et al. (1978) & $\begin{array}{l}\text { Net metabolic rate } \\
(\mathrm{kcal} / \text { lift })\end{array}$ & $\begin{array}{l}\text { Stoop lift } \\
(\mathrm{h} 1<\mathrm{h} 2 \leq 0.81)\end{array}$ & $\begin{array}{l}\text { NMR }=0.00325 * W *(0.81 \\
-h 1)+(0.0141 * L \\
+0.0076 * G * L) *(h 2-h 1)\end{array}$ \\
\hline Garg et al. (1978) & $\begin{array}{l}\text { Net metabolic rate } \\
(\mathrm{kcal} / \text { lift })\end{array}$ & $\begin{array}{l}\text { Squat lift } \\
(\mathrm{h} 1<\mathrm{h} 2 \leq 0.81)\end{array}$ & $\begin{array}{l}\text { NMR }=0.00514 * W *(0.81 \\
-h 1)+(0.0219 * L \\
+0.0062 * G * L) *(h 2-h 1)\end{array}$ \\
\hline Garg et al. (1978) & $\begin{array}{l}\text { Net metabolic rate } \\
\text { (kcal/lift) }\end{array}$ & $\begin{array}{l}\text { Arm lift } \\
(0.81<\mathrm{h} 1 \leq \mathrm{h} 2)\end{array}$ & $\begin{array}{l}\mathrm{NMR}=0.00352 * \mathrm{~W} *(0.81 \\
-\mathrm{h} 1)+0.0303 * \mathrm{~L} *(\mathrm{~h} 2-\mathrm{h} 1)\end{array}$ \\
\hline Asfour (1980) & $\begin{array}{l}\text { Oxygen consumption } \\
(\mathrm{ml} / \mathrm{min})\end{array}$ & $\begin{array}{l}\text { Lifting that starts at } \\
\text { floor and lowering } \\
\text { that ends at floor }\end{array}$ & $\begin{array}{l}\mathrm{V} 02=545.7538 \\
-106.4477 * \mathrm{TA}+10^{* *} \\
-6^{*} \mathrm{~F} \mathrm{~L}^{* *} 2 *(35002.65 \\
\left.-35058^{*} \mathrm{~L}\right)+17.47^{*} 10^{* *} \\
-6^{*} \mathrm{~F}^{*} \mathrm{~L}^{*} \mathrm{H} \mathrm{H}^{*} \mathrm{WID}{ }^{*} \\
\mathrm{LEN} * \mathrm{ANG}+16435.22 * 10^{* *} \\
-6^{*} \mathrm{~W}^{*} \mathrm{~F}^{* *} 2\end{array}$ \\
\hline Asfour (1980) & $\begin{array}{l}\text { Oxygen consumption } \\
(\mathrm{ml} / \mathrm{min})\end{array}$ & $\begin{array}{l}\text { Lifting that starts at } \\
\text { table height and } \\
\text { lowering that ends at } \\
\text { table height }\end{array}$ & $\begin{array}{l}\mathrm{V} 02=371.5055 \\
-51.9573^{*} \mathrm{TA}+10^{* *} \\
-6^{*} \mathrm{~W} \mathrm{~F}^{* *} 2 *(31856.54 \\
\left.-2332.8^{*} \mathrm{~F}\right) \\
+12684.91 * 10^{* *} \\
-6^{*} \mathrm{~F}^{*} \mathrm{~L}^{* *} 2+12.31 * 10^{* *} \\
-6^{*} \mathrm{~F}^{*} \mathrm{H}^{*} \mathrm{~L} * \mathrm{~W}^{*} \mathrm{LEN} * \text { ANG }\end{array}$ \\
\hline $\begin{array}{l}\text { Mital (1983b) and } \\
\text { Mital et al. (1984) }\end{array}$ & $\begin{array}{l}\text { Change of oxygen } \\
\text { consumption with } \\
\text { time }(\%)\end{array}$ & Lifting (males) & $\begin{array}{l}\text { CV02 }=103.763 \\
-13.497 * \mathrm{~T}+2.142 * \mathrm{~T}^{* * 2} \\
-0.117^{* * 3} \\
+0.00013 * \mathrm{EXP}(\mathrm{T})\end{array}$ \\
\hline $\begin{array}{l}\text { Mital (1983b) and } \\
\text { Mital et al. (1984) }\end{array}$ & $\begin{array}{l}\text { Change of oxygen } \\
\text { consumption with } \\
\text { time }(\%)\end{array}$ & Lifting (females) & $\begin{array}{l}\text { CV02 }=101.726-2.305 * \mathrm{~T} \\
+0.00003 * \operatorname{EXP}(\mathrm{T})\end{array}$ \\
\hline Mital et al. (1984) & $\begin{array}{l}\text { Oxygen consumption } \\
\text { (l/min) }\end{array}$ & $\begin{array}{l}\text { Lifting from floor to } \\
\text { knuckle }\end{array}$ & $\begin{array}{l}\text { V02 }=1.527-0.207 * \mathrm{G} \\
-0.005 * \text { Stature } \\
+0.0013 * \text { Back Strength } \\
-0.0002 * \text { Chest } \\
\text { Width** } 2+0.203 * \text { LOG } \\
\text { (Shoulder Strength) } \\
-0.408 * \text { LOG }(\text { Back } \\
\text { Strength }-0.02 * \text { Shift } \\
\text { Duration }+0.161 * \text { LOG }(\mathrm{F}) \\
+0.002 * \mathrm{~F} * \text { Lifting Capability } \\
-0.0007 * \mathrm{~F} * \text { Box Size }\end{array}$ \\
\hline Mital et al. (1984) & $\begin{array}{l}\text { Oxygen consumption } \\
\text { (l/min) }\end{array}$ & $\begin{array}{l}\text { Lifting from knuckle } \\
\text { to shoulder }\end{array}$ & $\begin{array}{l}\text { V02 }=0.047-0.117 * G \\
-0.003 * \text { Age }+0.0005 * \\
\text { Chest Depth**2 }\end{array}$ \\
\hline
\end{tabular}


Table 2 (Continued).

\begin{tabular}{|c|c|c|c|}
\hline Source & Dependent variable & Type of task & Model \\
\hline & & & $\begin{array}{l}\text { - } 0.00001 * \text { Composite } \\
\text { Strength**2 }-0.00005^{*} \\
\text { Back Strength ** } 2 \\
-0.175^{*} \mathrm{LOG}(\text { Arm } \\
\text { Strength }-0.0084 * \text { Shift } \\
\text { Duration }+0.004 * \mathrm{~F} * \text { Lifting } \\
\text { Capability }+0.00002 * \text { Box } \\
\text { Size }{ }^{*} \text { Lifting Capability }\end{array}$ \\
\hline Mital et al. (1984) & $\begin{array}{l}\text { Oxygen consumption } \\
\text { (l/min) }\end{array}$ & $\begin{array}{l}\text { Lifting from shoulder } \\
\text { to reach }\end{array}$ & $\begin{array}{l}\text { V02 }=-0.521-0.123 * \mathrm{G} \\
+0.004 * \mathrm{~W}+0.25 * \\
\text { LOG }(\text { Arm Strength) } \\
-0.008 * \text { Shift Duration } \\
+0.004 * \mathrm{~F} * \text { Lifting Capability } \\
+0.0003 * \text { Box Size * Lifting } \\
\text { Capability }\end{array}$ \\
\hline $\begin{array}{l}\text { Mital et al. (1984) } \\
\text { and Mital (1985) }\end{array}$ & $\begin{array}{l}\text { Oxygen consumption } \\
\text { (l/min) }\end{array}$ & Lifting for all heights & $\begin{array}{l}\text { V02 }=0.86-0.168 * \mathrm{G} \\
+0.00002 * \mathrm{~W}^{* *} 2 \\
-0.00012 * \text { Arm } \\
\text { Strength** } 2+0.279 * \\
\text { LOG(Arm Strength) } \\
-0.231 * \mathrm{LOG}(\text { Back } \\
\text { Strength) }-0.013 * \text { Shift } \\
\text { Duration }+0.004 * \mathrm{~F} * \text { Lifting } \\
\text { Capability }-0.00012 * \text { Box } \\
\text { Size * Lifting Capability }\end{array}$ \\
\hline $\begin{array}{l}\text { Karwowski and } \\
\text { Ayoub (1984a) }\end{array}$ & $\begin{array}{l}\text { Oxygen consumption } \\
\text { (l/min) }\end{array}$ & $\begin{array}{l}\text { Lifting from floor to } \\
76 \mathrm{~cm} \text { above floor }\end{array}$ & $\begin{array}{l}\text { V02 }=0.1659+0.004026 * \mathrm{~F} * \\
\text { Lifting Capability } \\
+0.0026887 * \text { Lifting } \\
\text { Capability }+0.002873 * \mathrm{~W} \\
-0.005854 * \text { Age } \\
+0.032699 * \mathrm{~F}\end{array}$ \\
\hline
\end{tabular}

(From Genaidy and Asfour, 1987; reprinted with permission. Copyright 1987 by the Human Factors and Ergonomics Society. All rights reserved.)

TEE - energy expenditure/hour

NMR - net metabolic rate for the activity performed

V02 - oxygen consumption ( $1 / \mathrm{min}$ for all studies, except Asfour in $\mathrm{ml} / \mathrm{min}$ )

CV02 - change of oxygen consumption with time (\%)

$\mathrm{W}$ - body weight (kg in Garg et al. and Mital et al.; pounds in Asfour)

$\mathrm{L}$ - amount of load handled ( $\mathrm{kg}$ in Garg et al. and Mital et al.; pounds in Asfour)

$\mathrm{G}$ - gender (Garg, et al.: male $=1$, female $=0$; Mital et al.: male $=1$, female $=2$ )

h1 - vertical height from floor (m); starting point for lift

h2 - vertical height from floor $(\mathrm{m})$; end point for lift

TA - type of task (lifting = 1, lowering = 2)

$\mathrm{F}$ - frequency of handling (times/min)

$\mathrm{H}$ - height of lift or lower (inches)

WID - box width (inches)

LEN - box length (inches)

ANG - angle of twist $\left(0^{\circ}\right.$ twist $=1 ; 90^{\circ}$ twist $\left.=2\right)$

$\mathrm{T}$ - shift duration (minutes)

All anthropometric measurements in $\mathrm{cm}$; isometric strengths in kg; lifting capability in kg; box size in inches; age in years; all models are valid for a duration of less than one hour, except those of Mital, which are valid up to 12 hours. 
Table 3. Energy cost prediction models for lowering tasks.

\begin{tabular}{|c|c|c|c|}
\hline Source & Dependent variable & Type of task & Model \\
\hline Garg et al. (1978) & $\begin{array}{l}\text { Net metabolic rate } \\
\text { (kcal/lower) }\end{array}$ & $\begin{array}{l}\text { Stoop lower } \\
(\mathrm{h} 1<\mathrm{h} 2 \leq 0.81)\end{array}$ & $\begin{array}{l}\text { NMR }=0.00268 * W *(0.81-h 1) \\
+0.00675 * L *(h 2-h 1) \\
+0.0522 * G *(0.81-h 1)\end{array}$ \\
\hline Garg et al. (1978) & $\begin{array}{l}\text { Net metabolic rate } \\
\text { (kcal/lower) }\end{array}$ & $\begin{array}{l}\text { Squat lower } \\
(\mathrm{h} 1<\mathrm{h} 2 \leq 0.81)\end{array}$ & $\begin{array}{l}\mathrm{NMR}=0.00511 * \mathrm{~W} *(0.81-\mathrm{h} 1) \\
+0.00701 * \mathrm{~L} *(\mathrm{~h} 2-\mathrm{h} 1)\end{array}$ \\
\hline Garg et al. (1978) & $\begin{array}{l}\text { Net metabolic rate } \\
\text { (kcal/lower) }\end{array}$ & $\begin{array}{l}\text { Arm lower } \\
(0.81<\mathrm{h} 1<\mathrm{h} 2)\end{array}$ & $\begin{array}{l}\text { NMR }=0.00093 * W *(h 2-0.81) \\
+(0.0102 * L \\
+0.0037 * G * L) *(h 2-h 1)\end{array}$ \\
\hline Asfour (1980) & $\begin{array}{l}\text { Oxygen consumption } \\
(\mathrm{ml} / \mathrm{min})\end{array}$ & $\begin{array}{l}\text { Lifting that starts } \\
\text { at table height and } \\
\text { lowering that ends } \\
\text { at table height }\end{array}$ & See Table 2 \\
\hline Asfour (1980) & $\begin{array}{l}\text { Oxygen consumption } \\
(\mathrm{ml} / \mathrm{min})\end{array}$ & $\begin{array}{l}\text { Lifting that starts } \\
\text { at floor level and } \\
\text { lowering that ends } \\
\text { at floor lever }\end{array}$ & See Table 2 \\
\hline $\begin{array}{l}\text { (From Genaidy a } \\
\text { Ergonomics Socie } \\
\text { NMR - net me } \\
\text { W - body wei } \\
\text { L - amount of } \\
\text { G - gender (m } \\
\text { h1 - vertical h } \\
\text { h2 - vertical h } \\
\text { All models are val }\end{array}$ & $\begin{array}{l}\text { Asfour, } 1987 \text {; reprin } \\
\text {. All rights reserved.) } \\
\text { abolic rate for activity p } \\
\text { ht }(\mathrm{kg}) \\
\text { oad lowered }(\mathrm{kg}) \\
l \mathrm{l}=1 \text {, female }=0) \\
\text { ight from floor }(\mathrm{m}) \text {; end } \\
\text { ight from floor }(\mathrm{m}) \text {; start }\end{array}$ & $\begin{array}{l}\text { ed } \\
\text { for lower } \\
\text { int for lower } \\
\text { e hour. }\end{array}$ & 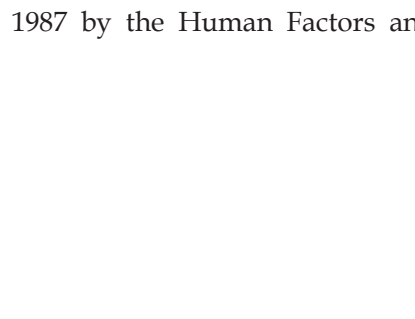 \\
\hline
\end{tabular}

Table 4. Cardiac cost prediction models for lifting tasks.

\begin{tabular}{|c|c|c|}
\hline Source & Type of Task & Model \\
\hline $\begin{array}{l}\text { Mital (1983b) and } \\
\text { Mital et al. (1984) }\end{array}$ & Lifting for males & $\begin{array}{l}\text { CHR }=104.846-16.85 * \text { Shift Duration } \\
+3.215 * \text { Shift Duration** } 2-0.184 * \text { Shift } \\
\text { Duration }^{* *} 3+0.0002 * \text { EXP }(\text { Shift Duration) }\end{array}$ \\
\hline $\begin{array}{l}\text { Mital (1983b) and } \\
\text { Mital et al. (1984) }\end{array}$ & Lifting for females & $\begin{array}{l}\text { CHR }=100.36-16.85 * \text { Shift Duration } \\
+0.00004 \text { EXP (Shift Duration) }\end{array}$ \\
\hline Mital et al. (1984) & $\begin{array}{l}\text { Lifting from floor to } \\
\text { knuckle height }\end{array}$ & $\begin{array}{l}\text { HR }=-112.342+14.677 * \text { G }-0.713 * \text { Iliac Crest } \\
\text { Height }-1.793 * \text { Chest Depth }+3.494 * \text { Abdominal } \\
\text { Depth }+12.078^{*} \text { RPI }-0.0045 * \text { (Back Strength) } * * 2 \\
+18.35 * \text { LOG }(\text { Arm Strength) } \\
+3.367 * \text { Frequency }-0.772 * \text { Shift Duration } \\
+1.885 * \text { Lifting Capability }-0.01 * \text { Box } \\
\text { Size * Lifting Capability }-0.48 * \text { Age }\end{array}$ \\
\hline Mital et al. (1984) & $\begin{array}{l}\text { Lifting from knuckle to } \\
\text { shoulder height }\end{array}$ & $\begin{array}{l}\text { HR }=1225.276+17.693 * \mathrm{G}+1.656 * \text { Abdominal } \\
\text { Depth }+7.37 * \text { RPI }+0.62 * \text { Back Strength } \\
+0.02 *(\text { Knee Height }) * * 2+0.0024 *(\text { Composite } \\
\text { Strength })^{* * 2}-0.0095 *(\text { Back Strength }) * 2 \\
-279.375 * \text { LOG }(\text { Stature })+37.582 * \text { LOG }(\text { Forearm }\end{array}$ \\
\hline
\end{tabular}


Table 4 (Continued).

\begin{tabular}{|c|c|c|}
\hline Source & Type of Task & Model \\
\hline & & $\begin{array}{l}\text { Grip Distance })-16.853 * \text { LOG }(\text { Chest Width }) \\
-0.986 * \text { Shift Duration }+0.231 \text { * Lifting } \\
\text { Capability * Frequency }+0.01 \text { * Box Size } \\
\text { * Lifting Capability }\end{array}$ \\
\hline \multirow{2}{*}{$\begin{array}{l}\text { Mital et at. (1984) } \\
\text { Composite }\end{array}$} & $\begin{array}{l}\text { Lifting from shoulder } \\
\text { to reach height }\end{array}$ & $\begin{array}{l}\text { HR }=39.176+17.015 * G-0.56 * \text { Iliac Crest } \\
\text { Height }+0.613 * \text { Arm Strength }-0.378 *\end{array}$ \\
\hline & & $\begin{array}{l}\text { Strength }+25.743 * \text { LOG }(\text { Back Strength }) \\
+0.003 *(\text { Composite Strength }) * 2-0.009 *(\text { Back } \\
\text { Strength }) * 2-1.32 * \text { Shift Duration }+6.43 * \text { LOG } \\
\text { (Frequency) }+0.067 * \text { Frequency * Lifting } \\
\text { Capability }+0.005 * \text { Box Size * Lifting Capability }\end{array}$ \\
\hline $\begin{array}{l}\text { Mital et al. (1984) } \\
\text { and Mital (1985) }\end{array}$ & Lifting for all heights & 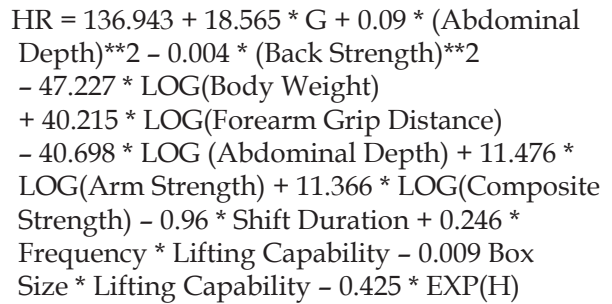 \\
\hline
\end{tabular}

(From Genaidy and Asfour, 1987; reprinted with permission. Copyright 1987 by the Human Factors and Ergonomics Society. All rights reserved.)

Anthropometric measurements in $\mathrm{cm}$

Isometric strengths in $\mathrm{kg}$

Frequency in lifts/minute

Lifting capability in $\mathrm{kg}$

Box size in inches

Body weight in $\mathrm{kg}$

$\mathrm{H}$ (height of lift): floor to knuckle $=1$, knuckle to shoulder $=2$, shoulder to reach $=3$

$\mathrm{G}$ (gender): male $=1$, female $=2$

Shift duration in hours

RPI $=$ Height $/ 3$ * ((Body Weight $\left.)^{* *} 0.333\right)$

Age in years

HR (heart rate) in beats/ $\mathrm{min}$

CHR (change in heart rate with time) in \%

All models are valid for a duration of up to 12 hours.

Mital (1983a) and Mital et al. (1984) developed oxygen consumption and heart-rate prediction models as a function of working time. The maximum weight of lift (MAWL) for these models was determined psychophysically. The oxygen consumption and heart rate associated with the maximum acceptable weight were recorded every two hours for 12 hours. The models are listed in Table 2.

In other studies, Mital (1985) and Mital et al. (1984) developed metabolic and cardiac prediction models for lifting tasks. The models were based on task variables as well as anthropometric and strength measurements using experienced subjects. Four lifting frequencies $(1,4,8,12$ times/min), three height levels (floor to knuckle, knuckle to shoulder, shoulder to reach), and three box sizes $(30.5,45.7,70.0 \mathrm{~cm}$ long in the sagittal plane) were 
used as the levels of the independent variables. The models developed showed low multiple R-square values (between 0.59 and 0.60). The models are listed in Table 2.

\section{Energy and cardiac cost models for carrying}

Morrissey and Liou (1984a, 1984b) conducted experiments to develop models to predict the energy cost of two handed carrying of loads in front of the body. Twenty-seven different carrying tasks were used on a level treadmill. The different variables involved in the carrying tasks were treadmill speed $(0.89,1.12,1.34,1.56,1.79 \mathrm{~m} / \mathrm{sec})$, container weight $(0,4.5,11.3,18.1,22.7 \mathrm{~kg})$, and container width in the sagittal plane $(15.2,22.8,30.5 \mathrm{~cm})$. Also included as variables were stature (as percentage of normal stature) and walking speeds. Regression models were developed to predict the steady state heart and metabolic rates; the regression models developed for oxygen consumption and heart rate are given in Tables 5 and 6.

Morrissey and Liou (1984c) also examined the physiological costs of carrying loads in erect and non-erect postures. Four trained male subjects carried loads on a level treadmill with a range of walking postures, container widths, container weights and walking speeds. The steady state oxygen uptake and heart rate required for task performance were measured and used to develop predictive equations.

Liou and Morrissey (1985) measured female physiological responses to load carrying with a variety of container widths, container weights and walking speeds on a level treadmill. The data obtained were then compared to data from males performing carrying tasks (Morrissey and Liou, 1984b). Regression models were developed to predict oxygen consumption and heart rate from the knowledge of gender, body weight, load carried, walking speed, and container width. The prediction equations for oxygen consumption and heart rate are provided in Tables 5 and 6.

\section{Evaluation of the models and their limitations}

Tables 2-7 summarize the metabolic and cardiac cost prediction models of various MMH tasks. Asfour (1980) and Ayoub et al. (1980) pointed out the following limitations of the energy cost prediction models developed by Aberg et al. (1968), Chaffin (1967), Frederick (1959), and Garg (1976):

(1) All models are only valid for manual materials handling tasks in the sagittal plane.

(2) They do not take into account the effect of task variables (e.g., frequency, height of handling, box width, and box length) and their interactions.

(3) Subjects were not trained before data collection.

(4) The model developed by Aberg et al. (1968) requires the determination of the body's center of gravity, which is difficult to perform.

(5) There is a need to measure the individual's standing metabolic rate in order to apply the models developed by Garg et al. (1978).

Asfour (1980) and Ayoub et al. (1980) reported that Garg's model for lifting tasks (1976) is the most flexible of all the metabolic rate prediction models developed prior to 1980 . However, this model was based on the assumption that the net total metabolic cost of a 
Table 5. Energy cost prediction models for carrying tasks.

\begin{tabular}{|c|c|c|c|}
\hline Source & Dependent variable & Type of task & Model \\
\hline Garg et al. (1978) & $\begin{array}{l}\text { Net metabolic rate } \\
(\mathrm{kcal} / \mathrm{min})\end{array}$ & $\begin{array}{l}\text { Carrying loads held at } \\
\text { arm's length at sides } \\
\text { (in one or both hands) }\end{array}$ & $\begin{array}{l}\mathrm{NMR}=0.8+\mathrm{O} . \mathrm{Q} 243 * \mathrm{~W} * \mathrm{~V} * * 2 \\
+0.0463 * \mathrm{~L} * \mathrm{~V} * * 2 \\
+0.0462 * \mathrm{~L} \\
+0.00379 *(\mathrm{~W}+\mathrm{L}) * \mathrm{TG} * \mathrm{~V}\end{array}$ \\
\hline Garg et al. (1978) & $\begin{array}{l}\text { Net metabolic rate } \\
(\mathrm{kcal} / \mathrm{min})\end{array}$ & $\begin{array}{l}\text { Carrying loads held } \\
\text { against thighs or } \\
\text { against waist }\end{array}$ & $\begin{array}{l}\text { NMR }=0.68 \\
+0.0254 * W^{*} V * * 2 \\
+0.048 * L^{*} V * * 2+0.114 * L \\
+0.00379 *(W+L) * T G * V\end{array}$ \\
\hline $\begin{array}{l}\text { Morrissey and Liou } \\
(1984 a)\end{array}$ & Metabolic rate (watts) & $\begin{array}{l}\text { Carrying loads in front } \\
\text { of body with both } \\
\text { hands }\end{array}$ & $\begin{array}{l}\mathrm{MR}=-181.66+7.18 * \mathrm{~W} \\
+189.45 * V * 2 \\
+3.63 * \mathrm{~L} * \mathrm{~V} * * 2+0.06 * \mathrm{~L} * \mathrm{Z} \\
-3.79 * \mathrm{~V} *(\mathrm{~W}+\mathrm{L}) \\
+17.76 *(\mathrm{~W} \\
+\mathrm{L}) *(\mathrm{~L} / \mathrm{W}) * 2\end{array}$ \\
\hline $\begin{array}{l}\text { Momssey and Liou } \\
(1984 b)\end{array}$ & Metabolic rate (watts) & $\begin{array}{l}\text { Carrying loads in front } \\
\text { of body with both } \\
\text { hands }\end{array}$ & $\begin{array}{l}M R=-75.14+3.11 * W \\
+V * * 2 *(2.72 * L+87.75) \\
+13.36 *(W+L) \\
*((L / W) * * 2)\end{array}$ \\
\hline $\begin{array}{l}\text { Morrissey and Liou } \\
(1984 c)\end{array}$ & $\begin{array}{l}\text { Oxygen consumption } \\
\text { (l/min) }\end{array}$ & $\begin{array}{l}\text { Carrying loads in front } \\
\text { of body with both } \\
\text { hands }\end{array}$ & $\begin{array}{l}\mathrm{V} 02=2.74-0.03 * \mathrm{P} \\
+(\mathrm{L} / \mathrm{W}) *[0.0016 * \mathrm{~V} * * 2 * \mathrm{Z} \\
-6.13 *(\mathrm{~L} / \mathrm{W})+2.49] \\
+(2.4 * 10 * \\
-3) * \mathrm{~V} *(\mathrm{~W}+\mathrm{L})\end{array}$ \\
\hline $\begin{array}{l}\text { Liou and Morrissey } \\
\text { (1985) }\end{array}$ & Metabolic rate (watts) & $\begin{array}{l}\text { Carrying loads in front } \\
\text { of body with both } \\
\text { hands }\end{array}$ & $\begin{array}{l}\mathrm{MR}=25.4+24.1 * 0 \\
+0.43 * \mathrm{Z} * \mathrm{~V} * * 2+(\mathrm{W} \\
+\mathrm{L}) *(3.16+2.54 * \mathrm{~V} * * 2 \\
+16 *((\mathrm{~L} / \mathrm{W}) * * 2) \\
-3.25 * \mathrm{~V})\end{array}$ \\
\hline
\end{tabular}

(From Genaidy and Asfour, 1987; reprinted with permission. Copyright 1987 by the Human Factors and Ergonomics Society. All rights reserved.)

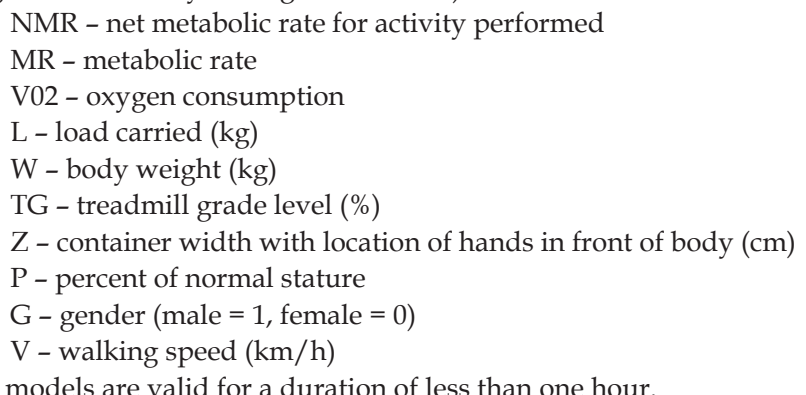

series of activities can be estimated by summing their net steady state individual metabolic costs as obtained from their performance separately. This assumption was reported to be invalid (Asfour, 1980; Genaidy et al., 1985a).

The models developed by Asfour (1980) for lifting and lowering tasks attempted to overcome the limitations of previous models developed prior to 1980. He employed 
Table 6. Cardiac cost prediction models for carrying tasks.

\begin{tabular}{|c|c|c|}
\hline Source & Dependent variable & Model \\
\hline Morrissey and Liou (1984a) & Heart rate (beats/min) & $\begin{array}{l}\mathrm{HR}-205.5+(\mathrm{W}+\mathrm{L}) *(2.34 *(\mathrm{~L} / \mathrm{W}) \\
+0.38 * \mathrm{~V} * 2-0.64 * \mathrm{~V}-1.53)\end{array}$ \\
\hline Morrissey and Liou (1984b) & Heart rate (beats / min) & $\begin{array}{l}\mathrm{HR}=192+27.39 * \mathrm{~V} *[(\mathrm{~V}-1.53) \\
+1.42(\mathrm{~W}+\mathrm{L}) *(1-1.46 *(\mathrm{~L} / \mathrm{W}))]\end{array}$ \\
\hline Morrissey and Liou (1984c) & Heart rate (beats/min) & $\begin{array}{l}\mathrm{HR}=227.6-16.8 * \mathrm{~W}+15.53 * \mathrm{~V} * 2 \\
+13.2 *(\mathrm{~L}+\mathrm{W})+0.03 * \mathrm{Z} * \mathrm{~L} \\
-8.9 *(\mathrm{~L} / \mathrm{W}) * \mathrm{P}\end{array}$ \\
\hline Liou and Morrissey (1985) & Heart rate (beats / min) & $\begin{array}{l}\mathrm{HR}=113.28-10.62 * \mathrm{G} \\
+21.45 * \mathrm{~V} * 2+2.01 *(\mathrm{~W}+\mathrm{L}) \\
*((\mathrm{~L} / \mathrm{W}) * * 2)+0.67 * \mathrm{~L} * \mathrm{~V} * 2 \\
-0.56 *(\mathrm{~W}+\mathrm{L}) * \mathrm{~V}\end{array}$ \\
\hline
\end{tabular}

(From Genaidy and Asfour, 1987; reprinted with permission. Copyright 1987 by the Human Factors and Ergonomics Society. All rights reserved.)

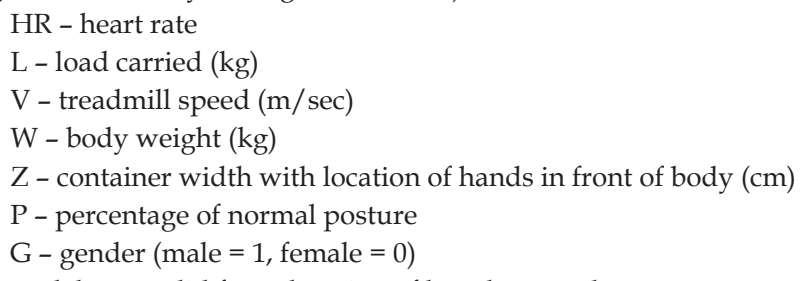

All models are valid for a duration of less than one hour.

Table 7. Energy cost prediction models for combined activities.

\begin{tabular}{|c|c|c|}
\hline Source & Type of task & Model \\
\hline Aberg et al. (1968) & $\begin{array}{l}\text { Lifting, lowering, } \\
\text { carrying, and dragging }\end{array}$ & $\begin{array}{l}\mathrm{V} 02=\mathrm{k} 1 * \mathrm{~W} \text { naked }+\mathrm{k} 2 * \mathrm{~W} \text { with } \\
\text { clothing } *\left(\mathrm{k} 3 * \mathrm{GCBh}+\mathrm{k} 4{ }^{*} \mathrm{GCBv}\right) \\
+(\mathrm{WWP}+\mathrm{WT}) *(\mathrm{k} 5 * \mathrm{Lha} \\
\left.+\mathrm{k} 6{ }^{*} \mathrm{Mu}{ }^{*} \mathrm{Lhc}+\mathrm{k} 7{ }^{*} \mathrm{Lvu}+\mathrm{k} 8 * \mathrm{Ivd}\right)\end{array}$ \\
\hline
\end{tabular}

(From Genaidy and Asfour, 1987; reprinted with permission. Copyright 1987 by the Human Factors and Ergonomics Society. All rights reserved.)

V02 - oxygen consumption $(1 / \mathrm{min})$

$\mathrm{W}$ - body weight $(\mathrm{kg})$

GCBh - horizontal displacement per time unit of the body's center of gravity $(\mathrm{m} / \mathrm{min})$

GCBv - vertical displacement per time unit of the body's center of gravity up plus down $(\mathrm{m} / \mathrm{min})$

WWP - weight of work piece $(\mathrm{kg})$

WT - weight of the tool $(\mathrm{kg})$

Lha - horizontal displacement per time unit of tool and work piece, arm work ( $\mathrm{m} / \mathrm{min})$

Lhc - horizontal displacement per time unit of tool and work piece, carrying or dragging $(\mathrm{m} / \mathrm{min})$

$\mathrm{Lvu}$ - upward vertical displacement per time unit of tool and work piece, lifting $(\mathrm{m} / \mathrm{min})$

Lvd - downward vertical displacement per time unit of tool and work piece, lowering $(\mathrm{m} / \mathrm{min})$

$\mathrm{Mu}$ - coefficient of friction in horizontal movement

k1 - k7 - constants

All models are valid for a duration of less than one hour. 
trained subjects for eight weeks on flexibility, cardiovascular endurance, muscular strength, and muscular endurance (Asfour et al., 1984b). Task variables such as frequency, height, box length, box width, and angle of body twist were incorporated in the models. Based on the database provided by Asfour (1980), Asfour et al. (1986a, 1986b), it is apparent that the frequency, load, height, and box size have a significant effect on the energy expenditure of individuals engaged in lifting and lowering tasks.

Morrissey and Liou's models (Liou and Morrissey, 1985; Morrissey and Liou, 1984a, 1984b, 1984c) were developed for carrying boxes with both hands. Their models did not take into account the effect of task variables and their interaction, except for box width. Mital and Asfour (1983) reported that carrying frequency, distance, and height are important parameters in the design of carrying tasks.

The major limitation of most of the models reported in the literature is that they are applicable only to manual tasks of less than 60 minutes duration. Thus, according to Genaidy and Asfour (1987), future models should address the effect of working time on the physiological responses of individuals engaged in MMH tasks.

The models generated by Mital (1983b, 1985) and Mital et al. (1984) are the only available models for manual lifting over prolonged periods. These models, however, have some limitations. A low correlation was obtained between task variables and oxygen consumption and heart rate. Mital and coworkers attributed the low correlation to the use of the psychophysical methodology to determine the amount of load that can be handled by individuals. Deivanayagam and Ayoub (1979) indicated that oxygen consumption tends to rise gradually over time while the external work output remained the same. This can be attributed to one of the following factors: a progressive accumulative effect of the products of metabolism; changes in blood flow distribution to various parts of the body other that the working muscles; deterioration in mechanical efficiency; or changes in the constitution of metabolic substrate involved in the energy-release processes.

Many investigators have considered manual materials handling tasks as a continuous type of activity. In fact, an MMH task can be regarded as a pulse function of two to three seconds duration. The gross assumption of a continuous $\mathrm{MMH}$ activity does not reflect the metabolic and cardiorespiratory peaks obtained at precisely the moment when the physical pulse loading is applied to the human body. Genaidy et al. (1985b) developed the following equations for the working and recovery curves for lowering an $18 \mathrm{~kg}$ load at a frequency of 3 times/ $\mathrm{min}$ from $76 \mathrm{~cm}$ above the floor to the floor:

(1) Working curve: heart rate (beats $/ \mathrm{min})=93.35-20.85^{*} \exp (-($ time in sec $) / 1.312)$.

(2) Recovery curve: heart rate (beats $/ \mathrm{min})=92.65^{*} \exp (-($ time in $\mathrm{sec}) / 67.637)$.

\section{PSYCHOPHYSICAL APPROACH}

Psychophysics deals with the relationship between human sensations and their physical stimuli. Borg (1962) and Eisler (1962) found that the perception of both muscular effort and force obey the psychophysical function where the sensation magnitude $S$ grows as a power function of the stimulus I. Stevens (1975) indicated that the strength of a sensation (S) is directly related to the intensity of its physical stimulus (I) by means of a power function:

$$
S=k * I^{n}
$$


Table 8. Net effect of work-related factors on acceptable weight/force.

\begin{tabular}{lll}
\hline Factor & MMH activity & Net effect \\
\hline Frequency $(\uparrow)$ & All & Decrease \\
Task duration $(\uparrow)$ & All & Decrease \\
Object size $(\uparrow)$ & All & Decrease \\
Object shape (various) & Lifting, carrying & \\
$\quad$ Collapsible (e.g. bags) & & Increase \\
$\quad$ Non-collapsible (e.g. metallic) & & Increase \\
$\quad$ volume increases) & & \\
$\quad$ Non-collapsible (volume does not change) & All & Unknown \\
Couplings (good) & Lifting, carrying & Increase \\
Load stability/distribution & Lifting, lowering & Decrease \\
Vertical lift height $(\uparrow)$ & Pulling, pushing & Decrease \\
Height of force $(\uparrow)$ & Lifting, lowering, carrying & Increase \\
$\quad$ Application/starting point & Decrease \\
Distance travelled $(\uparrow)$ & Pushing, pulling, carrying & Decrease \\
Speed/grade $(\uparrow)$ & Pushing, pulling, carrying & Decrease \\
Asymmetrical handling & Lifting, lowering & Decrease \\
\hline
\end{tabular}

(From Mital et al., 1997).

where:

$S=$ strength of a sensation,

$\mathrm{I}=$ intensity of physical stimulus,

$\mathrm{k}=\mathrm{a}$ constant which is a function of the particular units of measurement that are used,

$\mathrm{n}=$ the slope of the line that represents the power function when plotted in log-log coordinates. For example, it is equal to 3.5 for electric shock, and 1.6 for the perception of muscular effort and force. Stevens (1975) suggested an 'n' value of 1.45 for lifting weights.

Snook (1978) stated that psychophysics has been applied to practical problems in many areas, such as the scales of effective temperature, loudness and lightness, and ratings of perceived exertion (RPE). To apply the principle of psychophysics to men at work is to utilize the human capability to judge the subjectively perceived strain at work in order to determine voluntarily accepted work stresses. In terms of $\mathrm{MMH}$ activities, it can be used to determine what the subject can handle (capacity) without strain or discomfort. As stated by Legg and Myles (1981), with good subject cooperation and firm experimental control, the psychophysical method can identify loads that subjects can lift repetitively for an eight-hour workday without metabolic, cardiovascular or subjective evidence of fatigue. The measure of capacity used in this approach is 'maximum acceptable weight of lift.' Maximum acceptable weight of lift is generally defined as the maximum weight, determined experimentally that a given person could lift repeatedly for long periods of time without undue stress or fatigue.

A number of personal, work, and environmental factors affect the psychophysical design criterion. The details can be found in Ayoub and Mital (1989). Table 8 summarizes the net effect of some of the important work factors. 


\section{The psychophysical criterion}

The use of psychophysics in the study of lifting tasks requires a subject to adjust the weight of load according to his or her own perception of effort such that the repetitive lifting task does not result in overexertion or excessive fatigue. The final weight selected by the subject is considered to be the maximum acceptable weight (MAW) of lift for the given job conditions (frequency of lift, range of lift, container size, etc.). The MAW is the criterion used for design purposes. Because of the popularity of this approach, it has led to the development of capacity models which can predict lifting capacities (or MAW) for several lifting ranges with a reasonable degree of accuracy and confidence (Asfour, 1980; Asfour et al., 1984a, 1985; Ayoub et al., 1978a, 1983; Karwowski and Ayoub, 1984b; Mital, 1983a, 1983b, 1985).

\section{Psychophysical models}

McConville and Hertzberg (1966) investigated the optimum size of a container to be lifted with one hand. Boxes of various sizes (height remained constant) were used. The range of lift was from floor to $76 \mathrm{~cm}$ height. They indicated that the weight which 95 per cent of the population would be able to lift could be expressed as a function of object width.

Snook (1976) used data from previous studies by Snook et al. (1970) and Snook and Ciriello (1974) to develop a simple model to estimate the object weight to be lifted, based on frequency using a container size of $34 \times 48 \times 14 \mathrm{~cm}$ for floor to knuckle lift. These models are in the form:

$$
\begin{aligned}
& Y=14.23+5.53 X \text { for males } \\
& Y=13.64+1.6 X \text { for females }
\end{aligned}
$$

where:

$\mathrm{Y}=\mathrm{MAW}$ of lift $(\mathrm{kg})$,

$\mathrm{X}=$ frequency of lift in $\log$ seconds.

McDaniel (1972) developed a regression model to predict the acceptable weight of lift. The lifting task was defined as the maximum weight the subject was able to lift four times/ min for a period of $45 \mathrm{~min}$ without strain or unusual fatigue. The range of lift was from the floor to the standing knuckle height of the subject.

Dryden (1973) conducted a similar study to that of McDaniel. The subjects were asked to lift a tote box from their standing knuckle height through a range of $51 \mathrm{~cm}$. The frequency of lift was six lifts/min. Subjects were allowed to adjust their workloads by adding or removing weights from the tote box. A model to predict load of lift was developed using chest circumstance and dynamic endurance as independent variables.

Knipfer (1974) used female and male subjects to develop regression models for prediction of the load of lift. Subjects were asked to lift the box from standing shoulder height through a 51-cm range. The frequency of lift was six lifts/min. The independent variables of the model were back strength, shoulder strength, and age.

Aghazadeh (1974) conducted experiments and also used data by McDaniel (1972), Dryden (1973) and Knipfer (1974) to develop new predictive models. His approach was to establish the relationships between the lifting capacity for lifting from floor to knuckle 
height and the other two levels of lift, namely, lifting from knuckle height to shoulder height and from shoulder height to reach height. In addition, he included two other task variables - frequency of lift and box size. He simplified the prediction model using the relationship between the levels of lift and considering fewer operator variables and some task and container variables. The simplified model does not have as good an average error ratio as the individual models reported by McDaniel (1972), Dry den (1973) and Knipfer (1974). However, the simplified model has the following advantages (Ayoub and ElBassoussi, 1976):

(1) One model is used for all three levels of lift.

(2) One model is used for both males and females and such does not have gender as a variable.

(3) The model requires only two measurements of maximum isometric strengths: back strength and leg strength.

Table 9 shows these above-mentioned models, as summarized by Genaidy et al. (1988). Tables 10 and 11 give values for $C_{1}, C_{2}$, and $C_{3}$ for the models developed by Aghazadeh.

Ayoub et al. (1978b) conducted a study using industrial subjects to generate capacity data. Based on those data predictive models for the working population as well as individuals for different height levels as a function of operator and task variables were developed. Six different levels of lift were utilized (floor to knuckle, floor to shoulder, knuckle to shoulder, knuckle to reach, and shoulder to reach height) at rates of two, four, six and eight lifts/min. Three different box sizes were: $12 \times 7 \times 12,12 \times 7 \times 18$, and $12 \times 7 \times 24$ (width $\times$ depth $\times$ length, in). Various strength and anthropometric measurements were recorded for each subject. A stepwise linear regression analysis was employed to select the best prediction model. These models estimated an individual's lifting capacity.

Mital and Ayoub (1980) improved on the predictive models for lifting from data developed by Ayoub et al. (1978a). These models, in the form of regression equations, predicted an individual's MAW by using isometric strengths and personal characteristics (age, sex, and anthropometric variables). These revised models are shown in Table 12. Table 13 shows the multipliers to correct the predicted lift from the models for frequencies ranging from one to eight lifts/min.

Asfour (1980) proposed psychophysical lifting/lowering capacity models for two height ranges (start at floor or at 30 in above the floor). The variables incorporated in the models were the subject's body weight, frequency of lift, box size (width and length), and angle of body twist.

Garg and Ayoub (1980) conducted a psychophysical study to develop lifting capacity models by using a single strength (static or dynamic) variable. These models are attractive because of their simple form. They showed that the static vertical lift strength measured at the origin of lift significantly underestimated the dynamic lifting capacity as determined by psychophysical methodology. When the static vertical lift strength was performed closer to the body, such a bias was eliminated. They concluded that specific static strength tests must be carefully constructed to predict accurately a person's dynamic lifting capacity.

The arguments against lifting capacity models based on static strength tests are that actual lifting is dynamic in nature although temporary static components are involved (Aghazadeh and Ayoub, 1985; Kamon et al., 1982). Consequently, dynamic strength 
Table 9. Summary of psychophysical models.

\begin{tabular}{|c|c|c|c|c|c|c|}
\hline Researchers & $\begin{array}{l}\text { Dependent } \\
\text { variables }\end{array}$ & Height level & Male & Female & Both & Model \\
\hline \multirow{3}{*}{$\begin{array}{l}\text { McConville and } \\
\text { Hertzberg (1966) } \\
\text { Poulsen (1970) }\end{array}$} & $\begin{array}{l}\text { Maximum } \\
\text { weight of lift * }\end{array}$ & Floor to knuckle & $X$ & & & $\begin{array}{l}\text { Predicted lift }=60-\text { (width } \\
\text { of box in inches }\end{array}$ \\
\hline & $\begin{array}{l}\text { Maximum } \\
\text { weight of lift }\end{array}$ & Floor to table & & & $X$ & $\begin{array}{l}\text { Predicted lift }=1.40 \text { (max. } \\
\text { isometric back st.) }-0.50 \\
(\text { body wt) }\end{array}$ \\
\hline & & Table to head & & & $X$ & $\begin{array}{l}\text { Predicted lift }=0.50 \text { (sum of } \\
\text { right and left max. isometric } \\
\text { arm push) }\end{array}$ \\
\hline \multirow[t]{3}{*}{$\begin{array}{l}\text { McDaniel (1972); } \\
\text { Ayoub and } \\
\text { El-Bassoussi } \\
(1976)\end{array}$} & Load of lift ** & Floor to knuckle & $X$ & & & $\begin{array}{l}\text { Predicted lift }=172.36 \\
+0.02(\text { ht })^{2}-2.73 \text { (static } \\
\text { end. })^{2}+0.02(\mathrm{RPI}) \text { (arm st.) } \\
+0.05(\mathrm{RPI}) \text { (back st.) } \\
-2.51 \text { (Fl/dynamic end.) }\end{array}$ \\
\hline & Load of lift & Floor to knuckle & & $x$ & & $\begin{array}{l}\text { Predicted lift }=-24.03 \\
\quad+0.19(\mathrm{RPI})^{2}+0.006 \\
\text { (arm st.) (leg st.) }\end{array}$ \\
\hline & Load of lift & Floor to knuckle & & & $X$ & $\begin{array}{l}\text { Predicted lift }=11.93-1.12 \\
\quad\left(\text { back st.) }+0.16(\mathrm{RPI})^{2}\right. \\
+0.005 \text { (back st.) })^{2} \\
-8.81 \text { (static end.) }{ }^{2}-0.1 \\
(\text { sex })(\mathrm{Fl})+0.06(\mathrm{ht}) \\
(\mathrm{RPI})+0.03(\mathrm{RPI})(\text { leg st.) } \\
-0.002 \text { (back st.) (leg st.) } \\
-0.03 \text { (leg st.) (stat. end.) } \\
+0.11 \text { (static end.) (Fl) }\end{array}$ \\
\hline Dryden (1973) & Load of lift & $\begin{array}{l}\text { Knuckle to } \\
\text { shoulder }\end{array}$ & $X$ & & & $\begin{array}{l}\text { Predicted lift }=0.0 \\
\quad+0.83 \text { (chest circumference) } \\
+0.56 \text { (dynamic end.) }\end{array}$ \\
\hline \multirow[t]{2}{*}{$\begin{array}{l}\text { Ayoub and } \\
\text { El-Bassoussi } \\
(1976)\end{array}$} & Load of lift & $\begin{array}{l}\text { Knuckle to } \\
\text { shoulder }\end{array}$ & & $x$ & & $\begin{array}{l}\text { Predicted lift }=0.0+3.81 \\
\quad(\mathrm{RPI})-1.47(\mathrm{ht})(\mathrm{F} 1 / 1000) \\
-0.31(\mathrm{RPI})(\text { static end.) } \\
+1.23 \text { (percent fat) }(\mathrm{F} 1 / 1000)\end{array}$ \\
\hline & Load of lift & $\begin{array}{l}\text { Knuckle to } \\
\text { shoulder }\end{array}$ & & & $x$ & $\begin{array}{l}\text { Predicted lift }=25.12 \\
+0.38 \text { (sex) (dynamic end.) }\end{array}$ \\
\hline Knipfer (1974) & Load of lift & $\begin{array}{l}\text { Shoulder to } \\
\text { reach }\end{array}$ & $x$ & & & $\begin{array}{l}\text { Predicted lift }=4.91 \\
\quad+0.2 \text { (back st.) }-0.02 \\
\text { (shoulder st.) }+0.43 \text { (age) }\end{array}$ \\
\hline $\begin{array}{l}\text { Aghazadeh } \\
\text { (1974) }\end{array}$ & Load of lift & $\begin{array}{l}\text { Floor to knuckle, } \\
\text { knuckle to } \\
\text { shoulder, } \\
\text { shoulder to reach }\end{array}$ & 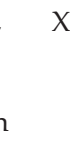 & & & $\begin{array}{l}\text { Predicted lift }=\left(C_{1} S\right. \\
\left.+C_{2}\right) C_{3}\left(C_{1}, C_{2}=\text { factor of }\right. \\
\text { freq. and height of lift; } \\
S=(\text { back st. } \times \text { leg st. }) / 1000\end{array}$ \\
\hline \multirow[t]{3}{*}{$\begin{array}{l}\text { Ayoub and } \\
\text { El-Bassoussi } \\
(1976)\end{array}$} & Load of lift & $\begin{array}{l}\text { Shoulder to } \\
\text { reach }\end{array}$ & & $x$ & & $\begin{array}{l}\text { Predicted lift }=0.34(\mathrm{wt}) \\
\quad+0.84(\text { dynamic end.) }+0.34 \\
\text { (forearm circumference) }\end{array}$ \\
\hline & Load of lift & $\begin{array}{l}\text { Shoulder to } \\
\text { reach }\end{array}$ & & & $X$ & $\begin{array}{l}\text { Predicted lift }=5.23 \text { (sex) } \\
\quad+0.005 \text { (shoulder st.) }+0.19 \\
\text { (horizontal push st.) }\end{array}$ \\
\hline & Load of lift & $\begin{array}{l}\text { Floor to knuckle, } \\
\text { knuckle to }\end{array}$ & & & $X$ & $\begin{array}{r}\text { Predicted lift }=13.19+13.85 \\
(\text { sex })+0.26 \text { (dynamic end.) }\end{array}$ \\
\hline
\end{tabular}
shoulder to reach 
Table 9 (Continued).

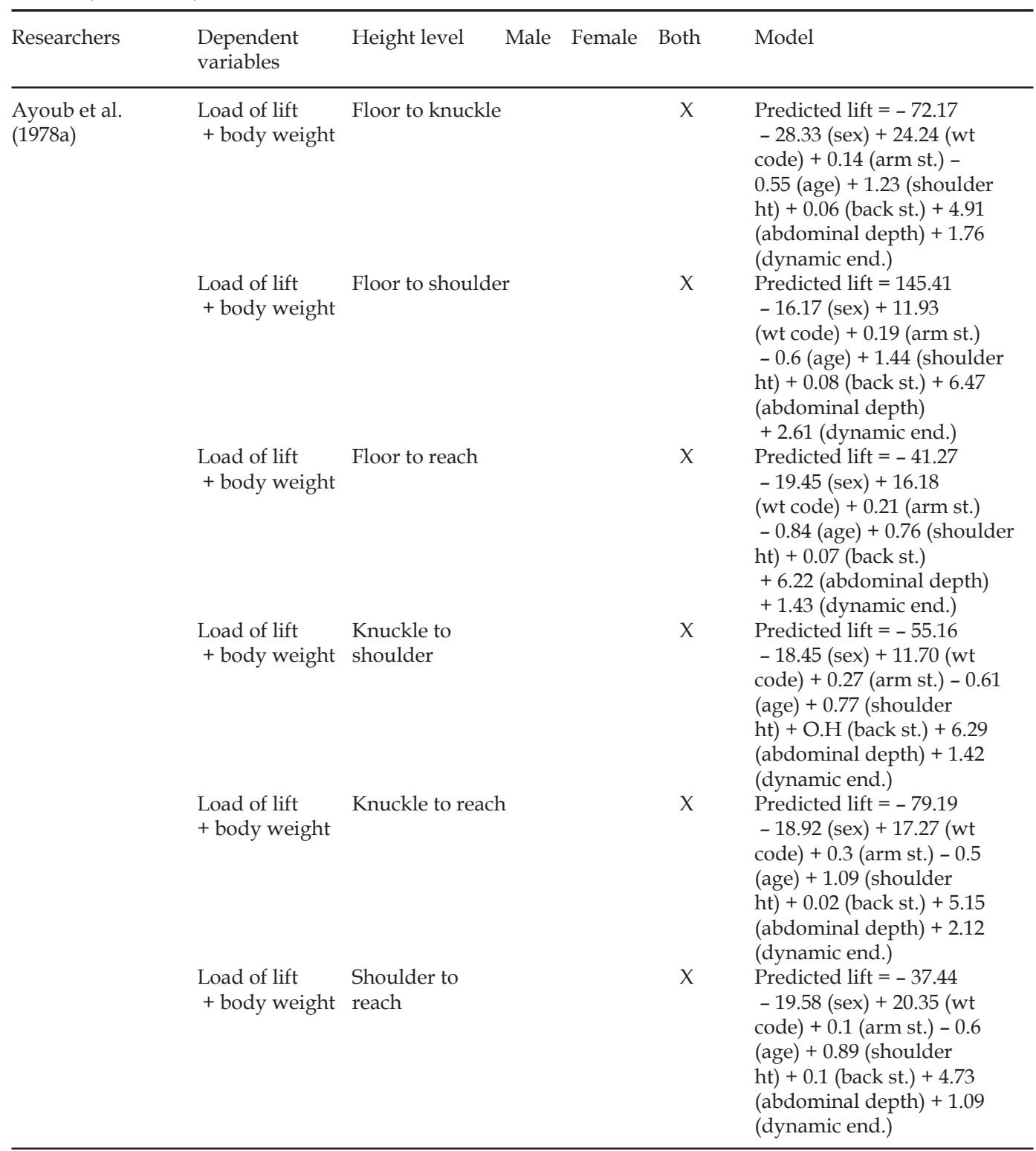

(From Ayoub et al., 1980; reprinted with permission. Copyright 1980 by the Human Factors and Ergonomics Society. All rights reserved.)

$\mathrm{RPI}=($ body ht $) \div(\text { body wt })^{1 / 3}$

$\mathrm{F} 1=100 \times$ duration of the step exercise $(\mathrm{s}) / 2 \times$ pulse recovery sum

* Maximum weight subjects could lift for non - repetitive lifting

** Maximum weight subjects were willing to lift for repetitive lifting

Lift ht ${ }^{*}=127 \mathrm{~cm}$ for floor to shoulder and 76 for shoulder to shoulder

See Table 10 for $\mathrm{C}_{1}$ and $\mathrm{C}_{2}$; see Table 11 for $\mathrm{C}_{3}$. 
Table 10. Factors for predicting acceptable amount of lift for different heights at different frequencies.

\begin{tabular}{llll}
\hline Frequency & & $\mathrm{C}_{1}$ & $\mathrm{C}_{2}$ \\
\hline \multirow{3}{*}{ Frequency of } & 1 & Knuckle height & \\
& 2 & 1.87 & 20.1 \\
& 3 & 1.77 & 19.1 \\
& 4 & 1.66 & 17.9 \\
Frequency of & 5 & 1.57 & 16.9 \\
& 6 & 1.48 & 15.9 \\
& 1 & 1.37 & 14.7 \\
& 2 & Shoulder height & \\
Frequency of & 3 & 2.49 & 43.6 \\
& 4 & 2.37 & 33.9 \\
& 5 & 2.22 & 29.5 \\
& 6 & 2.09 & 26.7 \\
& 1 & 1.97 & 24.6 \\
& 2 & Reach height & 22.4 \\
& 3 & 1.87 & 25.1 \\
& 4 & 1.79 & 26.8 \\
& 5 & 1.68 & 23.0 \\
& 6 & 1.57 & 20.6 \\
& & 1.48 & 18.9 \\
& & 1.37 & 17.2 \\
\hline
\end{tabular}

(From Ayoub et al., 1978b).

Table 11. Factors for box size.

\begin{tabular}{ll}
\hline $\begin{array}{l}\text { Box length } \\
\text { (dimension in sagittal plane) }\end{array}$ & Box size factor, $\mathrm{C}_{3}$ \\
\hline 10 & 1.00 \\
12 & 0.98 \\
14 & 0.95 \\
16 & 0.93 \\
18 & 0.90 \\
20 & 0.88 \\
22 & 0.86 \\
24 & 0.83 \\
26 & 0.81 \\
28 & 0.78 \\
30 & 0.76 \\
\hline
\end{tabular}

(From Ayoub et al., 1978a).

should play a more important role in lifting than static strength. In recent years, several researchers have developed psychophysical lifting capacity models based on dynamic strength tests.

Pytel and Kamon (1981) adapted a portable commercially available device ('MiniGym,' model 101) to measure isokinetic dynamic strength. A lifting experiment was de- 


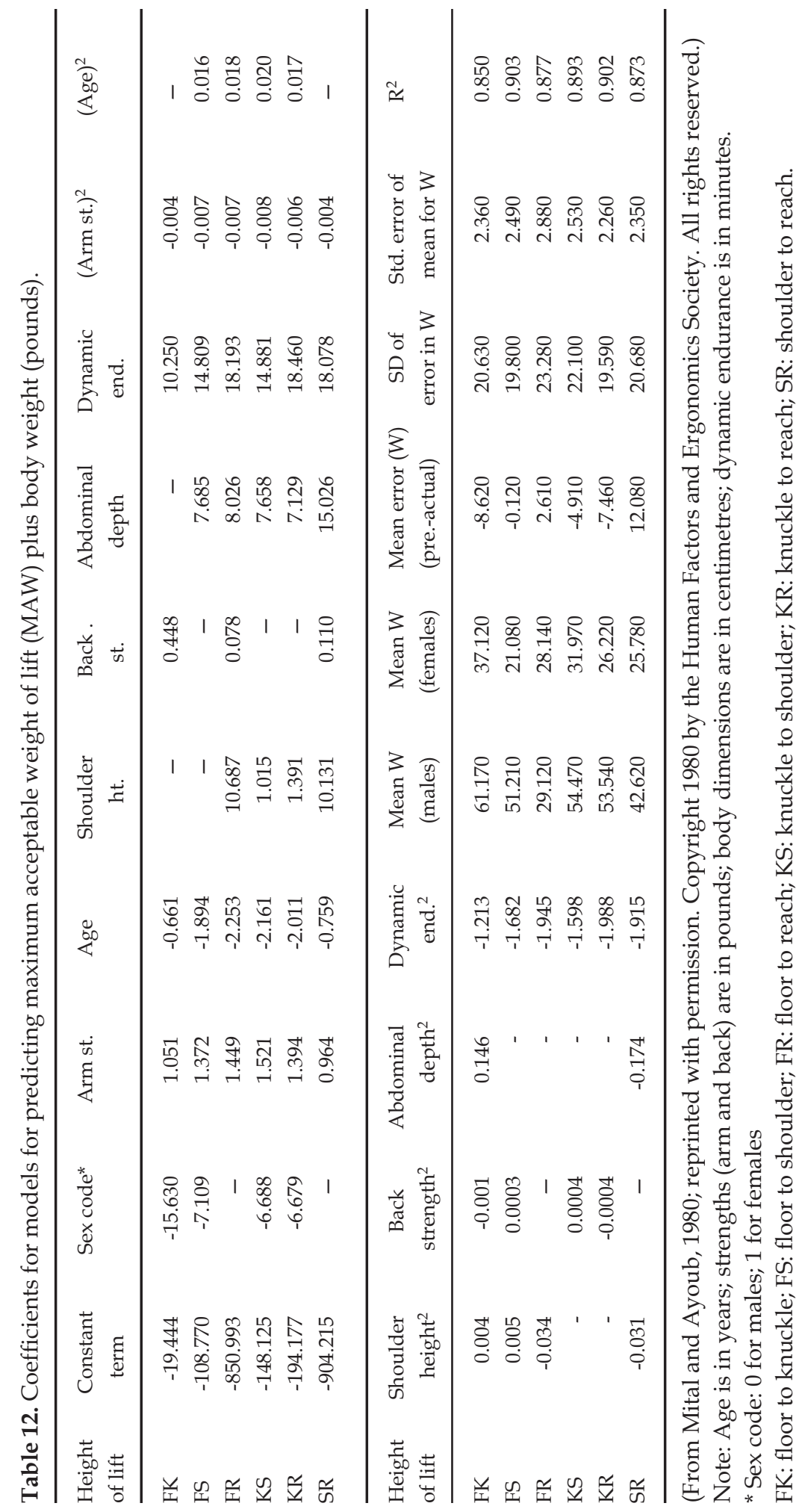


Table 13. Multipliers to adjust the maximum acceptable weight of lift for frequency.

\begin{tabular}{lllccccc}
\hline Height of lift & Sex & \multicolumn{7}{c}{ Frequency (lifts/min) } & & & & \\
& & 1 & 2 & 4 & 5 & 6 & 8 \\
\hline \multirow{2}{*}{ Floor to knuckle } & Male & 1.093 & 1.067 & 1.015 & 1.0 & 0.985 & 0.934 \\
& Female & 1.214 & 1.134 & 1.053 & 1.0 & 0.946 & 0.785 \\
Floor to shoulder & Male & 1.081 & 1.056 & 1.008 & 1.0 & 0.992 & 0.934 \\
& Female & 1.165 & 1.113 & 1.007 & 1.0 & 0.992 & 0.975 \\
Floor to reach & Male & 1.126 & 1.089 & 1.016 & 1.0 & 0.984 & 0.827 \\
& Female & 1.144 & 1.106 & 1.030 & 1.0 & 0.970 & 0.956 \\
Knuckle to shoulder & Male & 1.110 & 1.074 & 1.002 & 1.0 & 0.984 & 0.930 \\
& Female & 1.280 & 1.210 & 1.070 & 1.0 & 0.930 & 0.790 \\
Knuckle to reach & Male & 1.244 & 1.172 & 1.028 & 1.0 & 0.971 & 0.895 \\
\multirow{2}{*}{ Shoulder to reach } & Female & 1.017 & 1.009 & 1.008 & 1.0 & 0.991 & 0.935 \\
& Male & 1.071 & 1.059 & 1.036 & 1.0 & 0.964 & 0.874 \\
& Female & 1.196 & 1.147 & 1.049 & 1.0 & 0.950 & 0.901 \\
\hline
\end{tabular}

(From Mital and Ayoub, 1980; reprinted with permission. Copyright 1980 by the Human Factors and Ergonomics Society. All rights reserved.)

Table 14. Prediction models developed by Kamon et al. (1982).

\begin{tabular}{ll}
\hline $\mathrm{LC}=1.04 * \mathrm{EF}+330 ;$ & $\mathrm{r}=0.49$ \\
$\mathrm{LC}=1.65 * \mathrm{ES}+251 ;$ & $\mathrm{r}=0.47$ \\
$\mathrm{LC}=0.46 * \mathrm{BE}+380 ;$ & $\mathrm{r}=0.51$ \\
$\mathrm{LC}=0.54 * \mathrm{LS}+304 ;$ & $\mathrm{r}=0.47$ \\
$\mathrm{IL}=0.96 * \mathrm{BE}+254 ;$ & $\mathrm{r}=0.65$
\end{tabular}

where:

$$
\begin{aligned}
& \text { LC = lifting capacity (Newtons) } \\
& \mathrm{EF}=\text { elbow flexion, maximal contraction one arm } \\
& \mathrm{ES}=\text { elbow strength, dynamic flexion of two arms (isokinetic strength) } \\
& \mathrm{BE} \text { = back extension, maximum voluntary contraction } \\
& \mathrm{IL}=\text { isometric lift, static simulated lift } \\
& \mathrm{LS}=\text { lifting strength, simulated dynamic lift motion }
\end{aligned}
$$

signed to lift a tote box $(44 \mathrm{~cm} \times 30 \mathrm{~cm} \times 12 \mathrm{~cm})$ with handles from the floor to $113 \mathrm{~cm}$ height. A simple psychophysical model was developed using a simple strength test procedure, a concise form of the prediction models. However, $\mathrm{R}^{2}$ values were relatively low in this study. Only one lifting range (floor to $113 \mathrm{~cm}$ height) and one lifting frequency were studied.

Kamon et al. (1982) employed the same test procedure as Pytel and Kamon (1981) to test 228 male steelmill workers. Two psychophysical lifting models were developed by using a single static strength measure (back extension maximum voluntary contraction) or a single dynamic strength measure (lifting strength). The generated models are in the form of linear regression equations as shown in Table 14.

Aghazadeh (1983) studied the relationship between box/bag lifting capacity and the subject's strength test. Three task-related variables and five operator-related variables 
Table 15. Prediction models for the maximum acceptable weight of lift using dynamic strength.

\begin{tabular}{lcccccc}
\hline $\begin{array}{l}\text { Model } \\
\text { code }\end{array}$ & $\begin{array}{c}\text { Constant } \\
\text { term }\end{array}$ & $\begin{array}{l}\text { CONTAINR } \\
\text { coefficient }\end{array}$ & $\begin{array}{l}\text { LIFTTYPE } \\
\text { coefficient }\end{array}$ & $\begin{array}{l}\text { FRQNCY } \\
\text { coefficient }\end{array}$ & $\begin{array}{l}\text { DYNSTKS } \\
\text { coefficient }\end{array}$ & $R^{2}$ \\
\hline BXBDG & 54.72 & -9.68 & -0.11 & -2.21 & 0.27 & 0.726 \\
BGD & 43.18 & - & -0.18 & -1.91 & 0.21 & 0.594 \\
BXD & 37.21 & - & -0.03 & -2.52 & 0.34 & 0.775 \\
BXBGDKS & 41.37 & -7.52 & - & -2.21 & -0.36 & 0.778 \\
BXBGDFS & 51.02 & -9.68 & - & -2.21 & 0.27 & 0.706 \\
BGDKS & 29.94 & - & - & -1.87 & 0.30 & 0.725 \\
BGDFS & 43.96 & - & - & -1.94 & 0.11 & 0.452 \\
BXDKS & 30.24 & - & - & -2.55 & 0.41 & 0.795 \\
BXDFS & 41.82 & - & - & -2.49 & 0.27 & 0.798 \\
\hline
\end{tabular}

(From Aghazadeh, 1983).

Container code: CONTAINR $=1$ for box and 2 for bag

Lift type code: LIFTTYPE $=20$ for knuckle to shoulder height lift and 50 for floor to shoulder height lift

Frequency code: FRQNCY $=2$ for 2 lifts/min and 6 for 6 lifts/min

Knuckle to shoulder dynamic strength code: DYNSTKS, units are in foot pounds

General models for box and bag lifting (code BXBGD)

Models for bag lifting only (code BGD)

Models for box lifting only (code BXD)

Models for box and bag lifting from knuckle to shoulder height (code BXBGDKS)

Models for box and bag lifting from floor to shoulder height (code BXBGDFS)

Models for bag lifting from knuckle to shoulder height (code BGDKS)

Models for bag lifting from floor to shoulder height (code BGDFS)

Models for box lifting from knuckle to shoulder height (code BXDKS)

Models for box lifting from floor to shoulder height (code BXDFS).

were studied. Task variables were container type (bag or box), frequency of lift (two or six lifts/min) and lifting ranges floor to shoulder and knuckle to shoulder (FS and KS). Operator-related variables were static strength (arm, stooped back, standing back, composite, shoulder and leg), dynamic strength measured using Cybex isokinetic strength equipment (FS and KS), endurance (static and dynamic), PWC, subject's height and weight. Nine dynamic models and nine static models were developed (see Table 15). Both static models and dynamic models could predict the maximum acceptable lifting capacity with a reasonable degree of accuracy ( $R^{2}$ with the range of 0.452 to 0.862$)$. Aghazadeh and Ayoub (1985) developed models for prediction of weight lifting capacity of individuals incorporating static strengths and dynamic strengths of the individual in a simulated lifting position and task variables: height and frequency of lift. It was concluded that both the dynamic and static models could predict the maximum acceptable amount of lift with a reasonable degree of accuracy. The use of the dynamic model resulted in less absolute error between the actual and predicted load than the static model (reduction of 44 per cent).

Jiang (1984) developed prediction models for both individual and combined MMH activities and examined the relationship between individual and combined MMH activities. MMH capacity was defined as the maximum weight the subject was willing to handle plus his or her body weight for a period of one hour under the variable task conditions. 
Each activity was conducted under three different frequencies: one time maximum, one handling per min, and six handlings per min. The prediction models for the capacities of individual $\mathrm{MMH}$ activities were developed based on the isoinertial six feet weight incremental lifting test or the isometric back strength test. The isoinertial 6-ft incremental weight lifting test was proved to be the best predictor for the individual MMH activities. Since this type of strength test involved both static strength to overcome the inertial resistance and dynamic strength to move the weight to a pre-assigned location, it was recommended as the most promising single screening test.

Jiang et al. (1986) developed models to predict capacity for combined material handling activities. Four individual MMH activities were studied: lifting from floor to knuckle height (LFK); lifting from knuckle to shoulder height (LKS); lowering from knuckle to floor height (LOW); and carrying for $3.4 \mathrm{~m} \mathrm{(C).} \mathrm{Three} \mathrm{combined} \mathrm{MMH}$ activities were studied: lifting from floor to knuckle height and carrying $3.4 \mathrm{~m}$ (LC); lifting from floor to knuckle height, carrying $3.4 \mathrm{~m}$, and lifting from knuckle to shoulder height (LCL); and lifting from floor to knuckle height, carrying $3.4 \mathrm{~m}$, and lowering from knuckle to floor height (LCLO).

Three different approaches were used for the modeling of combined MMH capacities: modeling based on one limiting individual MMH capacity, modeling based on isoinertial $1.83 \mathrm{~m}$ maximum strength, and modeling based on fuzzy-set theory (the fuzzy-set theory model will be omitted from this discussion). Models were developed using simple and multiple regression, and were evaluated according to goodness of fit (in terms of $R^{2}$ values) and PRESS statistics. Both advantages and disadvantages were found for both model types. Unfortunately, these models have yet to be fully validated.

The basis for the first approach uses the limiting individual MMH capacity as a predictor. The limiting capacity usually occurs at the most stressful individual activity (or at the weakest joint of the body) used in handling the task. The limiting activity was derived from the minimal capacity of all the individual capacity elements that made up the $\mathrm{MMH}$ task. The individual models (for each of the three combined $\mathrm{MMH}$ activities - at each of the three frequency conditions) and their corresponding limiting activity and $\mathrm{R}^{2}$ values are shown in Table 16.

The key advantage of these limiting activity-based models is found in the incredibly high $\mathrm{R}^{2}$ values. Thus, these models had the best fit to the experimental data, in terms of $\mathrm{R}^{2}$ values. As a result, if the limiting individual MMH capacity is known, the combined $\mathrm{MMH}$ capacity can be predicted accurately, using the individual $\mathrm{MMH}$ capacity. The close relationship between combined activity and limiting individual activity provides a good framework for job design/redesign that involves combined $\mathrm{MMH}$ activity. Several disadvantages exist, however. First, the relationship between combined and individual limiting capacities has not been developed. Next, in order to have the best predicted results, these models should only apply within the range of the independent variables used in this study. Furthermore, it should be again noted that this study only encompassed the participation of 12 (male) subjects, a small sample. Finally, the testing procedure for limiting individual activities should follow the testing procedure used in this study.

The basis for the second approach uses isoinertial strength of lifting from floor to a height of $1.83 \mathrm{~m}$ (this isoinertial strength test will be denoted at T1). The principle involved in the modeling came from an effort to match an individual's physical condition to his MMH capacities. These models were developed and selected according to simplicity, goodness of fit, and representation of variables. Table 17 shows the individual models 
Table 16. Combined activity models by Jiang et al. (1986).

\begin{tabular}{lll}
\hline Combined activity & $\mathrm{R}^{2}$ & Limiting activity \\
\hline LCM $=0.762+(0.953-$ LFKM $)$ & 0.952 & LFKM \\
LCLM $=3.015+(0.973 *$ LKSM $)$ & 0.967 & LKSM \\
LCLOM $=-17.805+(1.602 *$ LFKM $)$ & 0.966 & LFKM \\
LC1 $=16.903+(0.809 \cdot 1[$ LFK1 $)$ & 0.980 & LFK1 \\
LCL1 $=-4.201+(1.022 *$ LKS1 $)$ & 0.963 & LKS1 \\
LCL01 $=27.777+(0.685 *$ LFK1 $)$ & 0.915 & LFK1 \\
LC6 $=-1.449+(0.969 *$ LFK6 $)$ & 0.941 & LFK6 \\
LCL6 $=7.126+(0.883 *$ LKS6 $)$ & 0.932 & LKS6 \\
LCL06 $=6.272+(0.867 *$ LFK6 $)$ & 0.920 & LFK6 \\
\hline
\end{tabular}

Lifting F - K (LFK):

LFKM - LFK at the frequency of one time maximum

LFK1 - LFK at the frequency of 1 handling/min

LFK6 - LFK at the frequency of 6 handlings/min

Lifting K $-\mathrm{S}$ (LKS):

LKSM - LKS at the frequency of one time maximum

LKS1 - LKS at the frequency of 1 handling/min

LKS6 - LKS at the frequency of 6 handlings/ $\mathrm{min}$

Lowering K - S (LOW):

LOWM - LOW at the frequency of one time maximum

LOW1 - LOW at the frequency of 1 handling/min

LOW6 - LOW at the frequency of 6 handlings/min

Two hand front carrying for 14 feet $(\mathrm{C})$ :

$\mathrm{CM}-\mathrm{C}$ at the frequency of one time maximum

$\mathrm{Cl}-\mathrm{C}$ at the frequency of 1 handling/ $\mathrm{min}$

$\mathrm{C} 6-\mathrm{C}$ at the frequency of 6 handlings/ $\mathrm{min}$

Lifting F - K + carrying $14 \mathrm{ft}$ (LC):

LCM - LC at the frequency of one time maximum

LC1 - LC at the frequency of 1 handling/ $\mathrm{min}$

LC6 - LC at the frequency of 6 handlings/ $\mathrm{min}$

Lifting F - K + carrying $14 \mathrm{ft}+$ lifting K-S (LCL):

LCLM - LCL at the frequency of one time maximum

LCL1 - LCL at the frequency of 1 handling/min

LCL6 - LCL at the frequency of 6 handlings/min

Lifting F - K + carrying $14 \mathrm{ft}+$ lowering K-F (LCLO):

LCLOM - LCLO at the frequency of one time maximum

LCL01 - LCLO at the frequency of 1 handling/ $\mathrm{min}$

LCL06 - LCLO at the frequency of 6 handlings/min

for each of the three combined MMH activities at each of the three frequency conditions and their corresponding $\mathrm{R}^{2}$ and PRESS values.

Some of the advantages of isoinertial strength-based models include: (1) combined $\mathrm{MMH}$ capacities can be predicted by simple strength testing which can be conducted in less than five minutes; (2) the combined MMH capacity can be predicted from strength testing, directly; (3) no knowledge of individual capacities is required; and (4) the isoinertial strength tests are more representative of actual industrial lifting activities than other tests. The disadvantages of isoinertial strength-based models are very similar to those dis- 
Table 17. Models to predict combined activities using $6 \mathrm{ft}$ incremental lift test.

\begin{tabular}{lll}
\hline The models & & $\mathrm{R}^{2}$ \\
\hline $\mathrm{LCM}$ & $=129.749-(1.642 * \mathrm{~T} 1)+\left(0.029249 * \mathrm{~T} 1^{2}\right)$ & 0.913 \\
$\mathrm{LCLM}$ & $=165.945-(2.545 * \mathrm{~T} 1)+\left(0.028413 * \mathrm{~T} 1^{2}\right)$ & 0.885 \\
LCLOM & $=126.811-(1.884 * \mathrm{~T} 1)+\left(0.033231 * \mathrm{~T} 1^{2}\right)$ & 0.916 \\
LC1 & $=144.735-(2.312 * \mathrm{~T} 1)+\left(0.027586 * \mathrm{~T} 1^{2}\right)$ & 0.947 \\
LCL1 & $=75.280-(0.009 * \mathrm{~T} 1)+\left(0.007132 * \mathrm{~T} 1^{2}\right)$ & 0.854 \\
LCL01 & $=139.556-(2.092 * \mathrm{~T} 1)+\left(0.024567 * \mathrm{~T} 1^{2}\right)$ & 0.923 \\
LC6 & $=99.641-(1.042 * \mathrm{~T} 1)+\left(0.015411 * \mathrm{~T} 1^{2}\right)$ & 0.790 \\
LCL6 & $=98.427-(0.999 * \mathrm{~T} 1)+\left(0.014337 * \mathrm{~T} 1^{2}\right)$ & 0.811 \\
LCL06 & $=120.787-(1.734 * \mathrm{~T} 1)+\left(0.020301 * \mathrm{~T} 1^{2}\right)$ & 0.846 \\
\hline
\end{tabular}

(From Jiang et al., 1986).

advantages presented above, for the limiting-activity-based models. First, a small sample size of 12 subjects was used to develop the above models. Also, the application of these models should be within the range of the T1 values used in this study $(47.7-79.5 \mathrm{~kg})$. Finally, the testing procedure using T1 in this study should be followed in order to measure the isoinertial strength of T1.

Most MMH prediction models have focused on lifting activities. Few models however were developed to predict capacity for lowering, pushing, pulling, and carrying tasks. These are briefly presented in Tables 18, 19, 20, and 21.

All of the models presented above can be used to predict individual capacities. Models to estimate population capacities have also been developed. Ayoub et al. (1983) developed population models to estimate the lifting capacities for the various percentiles of the population. These models were based on the data generated by Ayoub et al. (1978a) (see earlier section for more details on the variables in the study). Table 22 shows these models for both males and females.

\section{CONFLICTS BETWEEN CRITERIA BASED ON THE VARIOUS APPROACHES}

It is not surprising that criteria based on the principles of biomechanics, psychophysics, and physiology often provide $\mathrm{MMH}$ limits that are in conflict. These conflicts pose confusion for practitioners, and make selecting a proper limit troublesome. An example of the conflicts between the criteria is shown in Figure 3, which illustrates recommended loads as a function of frequency for a floor to shoulder lift. The example is based on Kirn's (1990) models using a $650 \mathrm{~kg}$ spinal compression limit and a $1 \mathrm{l} / \mathrm{min}$ physiological criteria for males. The biomechanical approach results in high-recommended weights for high-frequency tasks and the physiological approach results in high-recommended loads at low frequencies. The figure also illustrates how the psychophysical approach may be in conflict with the physiological approach. The most conservative approach to these conflicts is to consider all criteria simultaneously in order to estimate the recommended weight for lift as was proposed by Kim (1990). The NIOSH equations of 1981 and 1991 use an approach considering all three criteria to estimate the recommended weight limit (RWL). 
Table 18. Lowering capacity prediction models.

\begin{tabular}{|c|c|c|c|c|}
\hline Source & Height of lower & Gender & Model & $\mathrm{R}^{2}$ \\
\hline \multirow[t]{2}{*}{ Asfour (1980) } & HL1 & Male & $\begin{array}{l}\mathrm{LC}=7.2904-0.4887 *(10 * *-6) \\
* \mathrm{BS} 1{ }^{*} \mathrm{BS} 2 * \mathrm{AT} * \mathrm{~F} * \mathrm{HL} 1 \\
+613153.53 *(10 * *-6) * \mathrm{BW} \\
-145.03 *\left(10^{* *}-6\right) * \mathrm{BS} *(\mathrm{~F} * 3)\end{array}$ & 0.72 \\
\hline & HL2 & Male & $\begin{array}{l}\mathrm{LC}=0.9868-48.2692 *\left(10^{* *}-6\right) \\
* \mathrm{~F}^{*} \mathrm{BS} 1 * \mathrm{BS} 2 * \mathrm{AT} \\
+367670.51 *(10 * *-6) * \mathrm{BS} \\
-65.25^{*}\left(10^{* *}-6\right) * \mathrm{BW} *(\mathrm{~F} * 3)\end{array}$ & 0.70 \\
\hline Mital (1983c) & All & Both & $\begin{array}{l}\mathrm{LC}=15.12-7.85 *(1 / \mathrm{BS} 1) \\
+131.53 *(1 / \mathrm{HL} 3)-0.092 *(1 / \mathrm{F}) \\
-2.75{ }^{*} \mathrm{LN}(\mathrm{F})+1.58{ }^{*} \mathrm{G} * \mathrm{HL} \\
+0.344^{*} \mathrm{G} * \mathrm{~F}+0.034{ }^{*} \mathrm{BS} 1{ }^{*} \mathrm{HL} \\
+0.002{ }^{*} \mathrm{HS} 3{ }^{*} \mathrm{~F}+0.33{ }^{*} \mathrm{HL}{ }^{*} \mathrm{~F}\end{array}$ & 0.94 \\
\hline
\end{tabular}

(From Genaidy et al., 1988; reprinted with permission. Copyright 1988 by the Human Factors and Ergonomics Society. All rights reserved.)

HL1: height of lower above the floor $(\mathrm{cm})$

HL2: height of lower above table height $(\mathrm{cm})$

LC: lowering capacity $(\mathrm{kg})$

BS1: box length $(\mathrm{cm})$

BS2: box width $(\mathrm{cm})$

AT: angle of twist (dge)

F: frequency of lower (times/min)

BW: body weight $(\mathrm{kg})$

G: gender ( $\mathrm{G}=0$ for male and 1 for female)

HL: height of lower ( $\mathrm{HL}=1$ for floor to knuckle, 2 for knuckle to shoulder, and 3 for shoulder to reach)

HL3: vertical distance of lower $(\mathrm{cm})$.

The model developed by Mital (1983c) was based on the data generated by Snook (1978); all models are applicable only for the free - style lifting technique.

Table 19. Pushing capacity prediction models.

\begin{tabular}{lllc}
\hline Source & Gender & Model & $\mathrm{R}^{2}$ \\
\hline Mital (1983c) & Male & $\mathrm{PC}=17.29-0.166^{*} \mathrm{HD}-11.45^{*} \mathrm{~F}$ & 0.968 \\
& $+0.0013^{*}\left(\mathrm{HD}{ }^{* *} 2\right)$ & \\
& $+5.60 *(\mathrm{~F} * 2)+0.001 *(1 / \mathrm{F})$ & \\
& $+0.047^{*} \mathrm{HD} * \mathrm{~F}$ & 0.960 \\
& & \\
& & \\
& Female & $0.10 .31-0.134^{*} \mathrm{LN}(\mathrm{F})+6.17 * \mathrm{WXP}(\mathrm{F})$ & \\
& & $+0.056^{*} \mathrm{HD} * \mathrm{~F}$ & \\
& &
\end{tabular}

(From Genaidy et al., 1988; reprinted with permission. Copyright 1988 by the Human Factors and Ergonomics Society. All rights reserved.)

PC: pushing capacity $(\mathrm{kg})$

HD: horizontal distance of push (m)

F: frequency of push (times/min).

The model developed by Mital (1983c) was based on the data generated by Snook (1978). 
Table 20. Pulling capacity prediction models.

\begin{tabular}{|c|c|c|c|}
\hline Source & Gender & Model & $\mathrm{R}^{2}$ \\
\hline \multirow[t]{2}{*}{ Mital (1983c) } & Male & $\begin{array}{l}\mathrm{PC}=18.48-0.685 * \mathrm{~F}-0.0003 *(\mathrm{VD} * * 2) \\
+0.003 * \mathrm{VD} * \mathrm{~F}-0.5 * \mathrm{LN}(\mathrm{F})\end{array}$ & 0.978 \\
\hline & Female & $\begin{array}{l}\mathrm{PC}=15.03-0.394 * \mathrm{~F}-0.0003 *(\mathrm{VD} * * 2) \\
-0.331 * \mathrm{LN}(\mathrm{F})\end{array}$ & 0.945 \\
\hline
\end{tabular}

(From Genaidy et al., 1988; reprinted with permission. Copyright 1988 by the Human Factors and Ergonomics Society. All rights reserved.)

PC: pulling capacity $(\mathrm{kg})$

VD: vertical distance of pull (m)

F: frequency of pull (times/min).

The model developed by Mital (1983c) was based on the data generated by Snook (1978).

Table 21. Carrying capacity prediction models.

\begin{tabular}{lllc}
\hline Source & Gender & Model & $\mathrm{R}^{2}$ \\
\hline Mital (1983c) & Male & $\mathrm{CC}=77.27-12.46 * \mathrm{LN}(\mathrm{VD})-2.4$ * $\mathrm{LN}(\mathrm{HD})$ & 0.962 \\
& & $-0.011 *(1 / \mathrm{F})-2.01 * \mathrm{LN}(\mathrm{F})$ & \\
& Female & $\mathrm{CC}=46.49-0.239 * \mathrm{HD}-7.12 * \mathrm{LN}(\mathrm{VD})$ & 0.955 \\
& & $-0.0073 *(\mathrm{l}) \mathrm{F})-1.44 * \mathrm{LN}(\mathrm{F})+0.0003 * \mathrm{VD} * \mathrm{HD} * \mathrm{~F}$ &
\end{tabular}

(From Genaidy et al., 1988; reprinted with permission. Copyright 1988 by the Human Factors and Ergonomics Society. All rights reserved.)

CC: carrying capacity $(\mathrm{kg})$

VD: height at which load is carried $(\mathrm{cm})$

F: frequency of carry (times/min)

HD: horizontal distance of cany (m).

The model developed by Mital (1983c) was based on the data generated by Snook (1978).

Table 22. Lifting capacity prediction models.

\begin{tabular}{|c|c|c|c|c|}
\hline Gender & $\begin{array}{l}\text { Height } \\
\text { of lift }\end{array}$ & $\begin{array}{l}\text { Frequency } \\
\text { (times/min) }\end{array}$ & Box size & Model \\
\hline \multirow[t]{4}{*}{ Male } & F-K & $0.1<\mathrm{F}<1.0$ & $12<\mathrm{BS}<18$ & $\begin{array}{l}\mathrm{LC}=\left[57.2 * \mathrm{~F}^{* *}(-0.184697)\right]+[1.65 *(18 \\
-\mathrm{BS})]+\left[\mathrm{Z} * 16.86 * \mathrm{~F}^{* *}(-0.174197)\right]\end{array}$ \\
\hline & F-K & $0.1<\mathrm{F}<1.0$ & $\mathrm{BX}>18$ & $\begin{array}{l}\mathrm{LC}-\left[57.2 * \mathrm{~F}^{* *}(-0.184697)\right]+[0 / 8 *(18 \\
-\mathrm{BS})]+\left[\mathrm{Z} * 16.86 * \mathrm{~F}^{* *}(-0.174197)\right]\end{array}$ \\
\hline & F-K & $1.0<\mathrm{F}<12.0$ & $12<\mathrm{BS}<18$ & $\begin{array}{l}\mathrm{LC}=[57.2-2.0 *(\mathrm{~F}-1)]+[1.65 *(18 \\
-\mathrm{BS})]+[\mathrm{Z} *(16.86-0.5943 *(\mathrm{~F}-1))]\end{array}$ \\
\hline & F-K & $1.0<\mathrm{F}<12.0$ & BS $>18$ & $\begin{array}{l}\mathrm{LC}=[57.2-2.0 *(\mathrm{~F}-1)]+[0.8 *(18 \\
-\mathrm{BS})]+[\mathrm{Z} *(16.86-0.5964 *(\mathrm{~F}-1))]\end{array}$ \\
\hline \multirow[t]{4}{*}{ Male } & F-S & $0.1<\mathrm{F}<1.0$ & $12<\mathrm{BS}<18$ & $\begin{array}{l}\mathrm{LC}=\left[51.2 * \mathrm{~F}^{* *}(-0.184697)\right]+[1.65 *(18 \\
-\mathrm{BS})]+[\mathrm{Z} * 15.09 * \mathrm{~F} * *(-0.174197)]\end{array}$ \\
\hline & F-S & $0.1<\mathrm{F}<1.0$ & BS $>18$ & $\begin{array}{l}\mathrm{LC}=\left[51.2 * \mathrm{~F}^{* *}(-0.184697)\right]+[0.8 *(18 \\
-\mathrm{BS})]+[\mathrm{Z} * 15.09 * \mathrm{~F} * *(-0.174197)]\end{array}$ \\
\hline & F-S & $1.0<\mathrm{F}<12.0$ & $12<\mathrm{BS}<18$ & $\begin{array}{l}\mathrm{LC}=[51.2-2.0 *(\mathrm{~F}-1)]+[1.65 *(18 \\
-\mathrm{BS})]+[\mathrm{Z} *(15.09-0.5338 *(\mathrm{~F}-1))]\end{array}$ \\
\hline & F-S & $1.0<\mathrm{F}<12.0$ & BS $>18$ & $\begin{array}{l}\mathrm{LC}=[51.2-2.0 *(\mathrm{~F}-1)]+[0.8 *(18 \\
-\mathrm{BS})]+[\mathrm{Z} *(15.09-0.5338 *(\mathrm{~F}-1))]\end{array}$ \\
\hline
\end{tabular}


Table 22 (Continued).

\begin{tabular}{|c|c|c|c|c|}
\hline Gender & $\begin{array}{l}\text { Height } \\
\text { of lift }\end{array}$ & $\begin{array}{l}\text { Frequency } \\
\text { (times/min) }\end{array}$ & Box size & Model \\
\hline \multirow[t]{4}{*}{ Male } & F-R & $0.1<\mathrm{F}<1.0$ & $12<\mathrm{BS}<18$ & $\begin{array}{l}\mathrm{LC}=\left[49.1 * \mathrm{~F}^{* *}(-0.184697)\right]+[1.65 *(18 \\
-\mathrm{BS})]+\left[\mathrm{Z} * 14.47^{*} \mathrm{~F} * *(-0.174197)\right]\end{array}$ \\
\hline & $\mathrm{F}-\mathrm{R}$ & $0.1<\mathrm{F}<1.0$ & BS $>18$ & $\begin{array}{l}\mathrm{LC}=[49.1 * \mathrm{~F} * *(-0.184697)]+[0.8 *(18 \\
-\mathrm{BS})]+\left[\mathrm{Z} * 14.47^{*} \mathrm{~F}^{* *}(-0.174197)\right]\end{array}$ \\
\hline & $\mathrm{F}-\mathrm{R}$ & $1.0<\mathrm{F}<12.0$ & $12<\mathrm{BS}<18$ & $\begin{array}{l}\mathrm{LC}-[49.1-2.0 *(\mathrm{~F}-1)]+[1.65 *(18 \\
-\mathrm{BS})]+[\mathrm{Z} *(14.47-0.5119 *(\mathrm{~F}-1))]\end{array}$ \\
\hline & F-R & $1.0<\mathrm{F}<12.0$ & BS $>18$ & $\begin{array}{l}\mathrm{LC}=[49.1-2.0 *(\mathrm{~F}-1)]+[0.8 *(18 \\
-\mathrm{BS})]+[\mathrm{Z} *(14.47-0.5119 *(\mathrm{~F}-1))]\end{array}$ \\
\hline \multirow[t]{4}{*}{ Male } & K-S & $0.1<\mathrm{F}<1.0$ & $12<\mathrm{BS}<18$ & $\begin{array}{l}\mathrm{LC}=[52.8 * \mathrm{~F} * *(-0.138650)]+[1.10 *(18 \\
-\mathrm{BS})]+[\mathrm{Z} * 14.67 * \mathrm{~F} * *(-0.156762)]\end{array}$ \\
\hline & K-S & $0.1<\mathrm{F}<1.0$ & BS $>18$ & $\begin{array}{l}\mathrm{LC}=[52.8 * \mathrm{~F} * *(-0.138650)]+[0.8 *(18 \\
-\mathrm{BS})]+[\mathrm{Z} * 14.67 * \mathrm{~F} * *(-0.156762)]\end{array}$ \\
\hline & K-S & $1.0<\mathrm{F}<12.0$ & $12<\mathrm{BS}<18$ & $\begin{array}{l}\mathrm{LC}=[52.8-2.0 *(\mathrm{~F}-1)]+[1.10 *(18 \\
-\mathrm{BS})]+[\mathrm{Z} *(14.67-0.5534 *(\mathrm{~F}-1))]\end{array}$ \\
\hline & K-S & $1.0<\mathrm{F}<12.0$ & BS $>18$ & $\begin{array}{l}\mathrm{LC}=[52.8-2.0 *(\mathrm{~F}-1)]+[0.8 *(18 \\
-\mathrm{BS})]+[\mathrm{Z} *(14.67-0.5534 *(\mathrm{~F}-1))]\end{array}$ \\
\hline \multirow[t]{4}{*}{ Male } & $\mathrm{K}-\mathrm{R}$ & $0.1<\mathrm{F}<1.0$ & $12<\mathrm{BS}<18$ & $\begin{array}{l}\mathrm{LC}=50.0 * \mathrm{~F} * *(-0.138650)]+[1.10 *(18 \\
-\mathrm{BS})]+[\mathrm{Z} * 13.89 * \mathrm{~F} * \bullet \operatorname{lt}(-0.156762)]\end{array}$ \\
\hline & $\mathrm{K}-\mathrm{R}$ & $0.1<\mathrm{F}<1.0$ & BS $>18$ & $\begin{array}{l}\mathrm{LC}=[50.0 * \mathrm{~F} * *(-0.138650)]+[0.8 *(18 \\
-\mathrm{BS})]+[\mathrm{Z} * 13.89 * \mathrm{~F} * *(-0.156762)]\end{array}$ \\
\hline & $\mathrm{K}-\mathrm{R}$ & $1.0<\mathrm{F}<12.0$ & $12<\mathrm{BS}<18$ & $\begin{array}{l}\mathrm{LC}=[50.0-2.0 *(\mathrm{~F}-1)]+[\mathrm{I} . \mathrm{IO} * \wedge \\
-\mathrm{BS})]+[\mathrm{Z} * 13.89-0.5240 *(\mathrm{~F}-1))]\end{array}$ \\
\hline & K-R & $1.0<\mathrm{F}<12.0$ & BS $>18$ & $\begin{array}{l}\mathrm{LC}=[50.0-2.0 *(\mathrm{~F}-1)]+[0.8 *(18 \\
\left.\left.-\mathrm{BS})]+\left[\mathrm{Z} * 13.89-0.5240^{\wedge}-1\right)\right)\right]\end{array}$ \\
\hline \multirow[t]{4}{*}{ Male } & S-R & $0.1<\mathrm{F}<1.0$ & $12<\mathrm{BS}<18$ & $\begin{array}{l}\mathrm{LC}=\left[48.4 * \mathrm{~F}^{* *}(-0.138650)\right]+[1.10 *(18 \\
-\mathrm{BS})]+\left[\mathrm{Z} * 13.45^{*} \mathrm{~F}^{* *}(-0.156762)\right]\end{array}$ \\
\hline & S-R & $0.1<\mathrm{F}<1.0$ & BS $>18$ & $\begin{array}{l}\mathrm{LC}=[48.4 * \mathrm{~F} * *(-0.138650)]+[0.8 *(18 \\
-\mathrm{BS})]+\left[\mathrm{Z} * 13.45^{*} \mathrm{~F} * *(-0.156762)\right]\end{array}$ \\
\hline & S-R & $1.0<\mathrm{F}<12.0$ & $12<\mathrm{BS}<18$ & $\begin{array}{l}\mathrm{LC}=[48.4-2.0 *(\mathrm{~F}-1)]+[1.10 *(18 \\
-\mathrm{BS})]+[\mathrm{Z} *(13.45-0.5074 *(\mathrm{~F}-1))]\end{array}$ \\
\hline & S-R & $1.0<\mathrm{F}<12.0$ & BS $>18$ & $\begin{array}{l}\mathrm{LC}=[48.4-2.0 *(\mathrm{~F}-1)]+[0.8 *(18 \\
-\mathrm{BS})]+[\mathrm{Z} *(13.45-0.5074 *(\mathrm{~F}-1))]\end{array}$ \\
\hline \multirow[t]{4}{*}{ Female } & F-K & $0.1<\mathrm{F}<1.0$ & $12<\mathrm{BS}<18$ & $\begin{array}{l}\mathrm{LC}=[37.4 * \mathrm{~F} * *(-0.187818)]+[1.10 *(18 \\
-\mathrm{BS})]^{*}[\mathrm{Z} * 6.87 * \mathrm{~F} * *(-0.251605)]\end{array}$ \\
\hline & F-K & $0.1<\mathrm{F}<1.0$ & BS $>18$ & $\begin{array}{l}\mathrm{LC}-\left[37.4 * \mathrm{~F}^{* *}(-0.187818)\right]+[0.4 *(18 \\
-\mathrm{BS})]+\left[\mathrm{Z} * 6.87^{*} \mathrm{~F} * *(-0.251605)\right]\end{array}$ \\
\hline & F-K & $1.0<\mathrm{F}<12.0$ & $12<\mathrm{BS}<18$ & $\begin{array}{l}\mathrm{LC}=[37.4-1.1 *(\mathrm{~F}-1)]+[1.10 *(18 \\
-\mathrm{BS})]+[\mathrm{Z} *(6.87-0.1564 *(\mathrm{~F}-1))]\end{array}$ \\
\hline & F-K & $1.0<\mathrm{F}<12.0$ & BS $>18$ & $\begin{array}{l}\mathrm{LC}=[37.4-1.1 *(\mathrm{~F}-1)]+[0.40 *(18 \\
-\mathrm{BS})]+[\mathrm{Z} *(6.87-0.1564 *(\mathrm{~F}-1))]\end{array}$ \\
\hline \multirow[t]{4}{*}{ Female } & F-S & $0.1<\mathrm{F}<1.0$ & $12<\mathrm{BS}<18$ & $\begin{array}{l}\mathrm{LC}=\left[31.1 * \mathrm{~F}^{* *}(-0.187818)\right]+[1.10 *(18 \\
-\mathrm{BS})]+[\mathrm{Z} * 5.71 * \mathrm{~F} * *(-0.251605)]\end{array}$ \\
\hline & F-S & $0.1<\mathrm{F}<1.0$ & BS $>18$ & $\begin{array}{l}\mathrm{LC}=[31.1 * \mathrm{~F} * *(-0.187818)]+[0.4 *(18 \\
-\mathrm{BS})]+\left[\mathrm{Z} * 5.71^{*} \mathrm{~F}^{* *}(-0.251605)\right]\end{array}$ \\
\hline & F-S & $1.0<\mathrm{F}<12.0$ & $12<\mathrm{BS}>18$ & $\begin{array}{l}\mathrm{LC}=[31.1-1.1 *(\mathrm{~F}-1)]+[1.10 *(18 \\
-\mathrm{BS})]+[\mathrm{Z} *(5.71-0.1300 *(\mathrm{~F}-1))]\end{array}$ \\
\hline & F-S & $1.0<\mathrm{F}<12.0$ & BS $>18$ & $\begin{array}{l}\mathrm{LC}=[31.1-1.1 *(\mathrm{~F}-1)]+[0.4 *(18 \\
-\mathrm{BS})]+[\mathrm{Z} *(5.71-0.1300 *(\mathrm{~F}-1))]\end{array}$ \\
\hline
\end{tabular}


Table 22 (Continued).

\begin{tabular}{|c|c|c|c|c|}
\hline Gender & $\begin{array}{l}\text { Height } \\
\text { of lift }\end{array}$ & $\begin{array}{l}\text { Frequency } \\
\text { (times/min) }\end{array}$ & Box size & Model \\
\hline \multirow[t]{3}{*}{ Female } & F-R & $0.1<\mathrm{F}<1.0$ & $12<\mathrm{BS}<18$ & $\begin{array}{l}\mathrm{LC}=\left[28.1 * \mathrm{~F}^{* *}(-0.187818)\right]+[1.10 *(18 \\
-\mathrm{BS})]+\left[\mathrm{Z} * 5.16^{*} \mathrm{~F} * *(-0.251605)\right]\end{array}$ \\
\hline & $\mathrm{F}-\mathrm{R}$ & $0.1<\mathrm{F}<1.0$ & BS $>18$ & $\begin{array}{l}\mathrm{LC}=\left[28.1 * \mathrm{~F}^{* *}(-0.187818)\right]+[0.4 *(18 \\
-\mathrm{BS})]+\left[\mathrm{Z} * 5.16^{*} \mathrm{~F}^{* *}(-0.251605)\right]\end{array}$ \\
\hline & $\mathrm{F}-\mathrm{R}$ & $1.0<\mathrm{F}<12.0$ & BS $>18$ & $\begin{array}{l}\mathrm{LC}=[28.1-1.1 *(\mathrm{~F}-1)]+[0.4 *(18 \\
-\mathrm{BS})]+[\mathrm{Z} *(5.16-0.1175 *(\mathrm{~F}-1))]\end{array}$ \\
\hline \multirow[t]{2}{*}{ Female } & K-S & $0.1<\mathrm{F}<1.0$ & $12<\mathrm{BS}<18$ & $\begin{array}{l}\mathrm{LC}=[30.8 * \mathrm{~F} * *(-0.156150)]+[0.55 *(18 \\
-\mathrm{BS})]+\left[\mathrm{Z} * 5.66^{*} \mathrm{~F} * \bullet \operatorname{lt}(-0.258700)\right]\end{array}$ \\
\hline & K-S & $0.1<\mathrm{F}<1.0$ & BS $>18$ & $\begin{array}{l}\mathrm{LC}=\left[30.8 * \mathrm{~F}^{* *}(-0.156150)\right]+[0.2 *(18 \\
-\mathrm{BS})]+\left[\mathrm{Z} * 5.66 * \mathrm{~F}^{* *}(-0.258700)\right]\end{array}$ \\
\hline \multirow[t]{2}{*}{ Female } & K-S & $1.0<\mathrm{F}<12.0$ & $12<\mathrm{BS}<18$ & $\begin{array}{l}\mathrm{LC}=[30.8-1.1 *(\mathrm{~F}-1)]+[0.55 *(18 \\
-\mathrm{BS})]+[\mathrm{Z} *(5.66-0.1289 *(\mathrm{~F}-1))]\end{array}$ \\
\hline & K-S & $1.0<\mathrm{F}<12.0$ & BS $>18$ & $\begin{array}{l}\mathrm{LC}=[30.8-1.1 *(\mathrm{~F}-1)]+[0.2 *(18 \\
-\mathrm{BS})]+[\mathrm{Z} *(5.66)-0.1289 *(\mathrm{~F}-1))]\end{array}$ \\
\hline \multirow[t]{4}{*}{ Female } & $\mathrm{K}-\mathrm{R}$ & $0.1<\mathrm{F}<1.0$ & $12<\mathrm{BS}<18$ & $\begin{array}{l}\mathrm{LC}=\left[27.3 * \mathrm{~F}^{* *}(-0.156150)\right]+[0.55 *(18 \\
-\mathrm{BS})]+[\mathrm{Z} * 5.01 * \mathrm{~F} * *(-0.258700)]\end{array}$ \\
\hline & $\mathrm{K}-\mathrm{R}$ & $0.1<\mathrm{F}<1.0$ & BS $>18$ & $\begin{array}{l}\mathrm{LC}=\left[27.3 * \mathrm{~F}^{* *}(0.156150)\right]+[0.2 *(18 \\
-\mathrm{BS})]+[\mathrm{Z} * 5.01 * \mathrm{~F} * *(-0.258700)]\end{array}$ \\
\hline & $\mathrm{K}-\mathrm{R}$ & $1.0<\mathrm{F}<12.0$ & $12<\mathrm{BS}<18$ & $\begin{array}{l}\mathrm{LC}-[27.3-1.1 *(\mathrm{~F}-1)]+[0.55 *(18 \\
-\mathrm{BS})]+[\mathrm{Z} *(5.01-0.1141 *(\mathrm{~F}-1))]\end{array}$ \\
\hline & $\mathrm{K}-\mathrm{R}$ & $1.0<\mathrm{F}<12.0$ & BS $>18$ & $\begin{array}{l}\mathrm{LC}==[27.3-1.1 *(\mathrm{~F}-1)]+[0.20 * 08 \\
-\mathrm{BS})]+[\mathrm{Z} *(5.01-0.1141 *(\mathrm{~F}-1))]\end{array}$ \\
\hline \multirow[t]{4}{*}{ Female } & S-R & $0.1<\mathrm{F}<1.0$ & $12<\mathrm{BS}<18$ & $\begin{array}{l}\mathrm{LC}=\left[26.4 * \mathrm{~F}^{* *}(-0.156150)\right]+[0.55 *(18 \\
-\mathrm{BS})]+\left[\mathrm{Z} * 4.85 * \mathrm{~F}^{* *}(-0.258700)\right]\end{array}$ \\
\hline & S-R & $0.1<\mathrm{F}<1.0$ & BS $>18$ & $\begin{array}{l}\mathrm{LC}=\left[26.4 * \mathrm{~F}^{* *}(-0.156150)\right]+[0.2 *(18 \\
-\mathrm{BS})]+\left[\mathrm{Z} * 4.85^{*} \mathrm{~F}^{* *}(-0.258700)\right]\end{array}$ \\
\hline & S-R & $1.0<\mathrm{F}<12.0$ & $12<\mathrm{BS}<18$ & $\begin{array}{c}\mathrm{LC}=[26.4-1.1 *(\mathrm{~F}-1)]+[0.55 *(18 \\
-\mathrm{BS})]+[\mathrm{Z} *(4.85-0.1104 *(\mathrm{~F}-1))]\end{array}$ \\
\hline & S-R & $1.0<\mathrm{F}<12.0$ & BS $>18$ & $\begin{array}{l}\mathrm{LC}=[26.4-1.1 *(\mathrm{~F}-1)]+[0.2 *(18 \\
-\mathrm{BS})]+[\mathrm{Z} *(4.85-0.1104 *(\mathrm{~F}-1))]\end{array}$ \\
\hline
\end{tabular}

(From Ayoub et al., 1983).

F: frequency of lift

BS: box size (inches)

LC: lifting capacity (pounds)

F-K: floor to knuckle

F-S: floor to shoulder

F-R: floor to reach

K-S: knuckle to shoulder

K-R: knuckle to reach

S-R: shoulder to reach

$Z$ : score of population percentage from normal tables $(Z=-1.6449$ for $95 \%, Z=-1.2816$ for $90 \%, Z=$ -1.0364 for $85 \%, Z=-0.6745$ for $75 \%, Z=0.0$ for $50 \%, Z=0.6745$ to $25 \%, Z=1.0364$ for $15 \%, Z-1.2816$ for $10 \%$, and $Z-1.6449$ for $5 \%$ ).

Models are based on the data generated by Snook (1978) and Ayoub et al. (1978a) and are applicable only for the free-style lifting technique. 


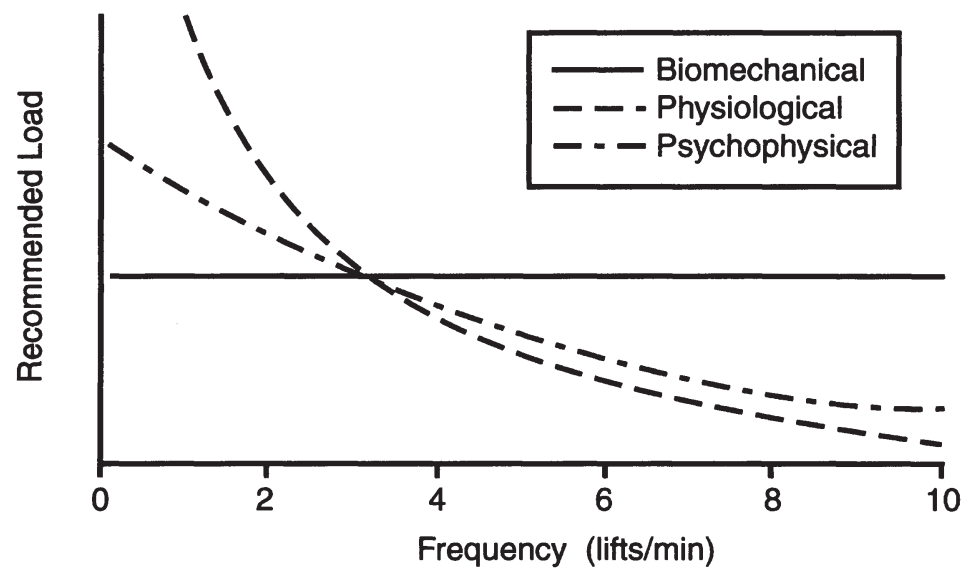

Figure 3. Example of conflict among biomechanical, psychophysical, and physiological criteria (based on Kirn's (1990) models).

\section{THE FUTURE OF MANUAL MATERIALS HANDLING MODELING}

As documented in this chapter, previous research to model and understand the adverse effects of manual materials handling tasks on workers has come from three distinctly different approaches. Each has provided insight into the hazards of individual task components that are often encountered in many jobs. Unfortunately, each approach is specifically directed at task components and none of these approaches has proven effective at dealing with jobs in their entirety. At the present time typical manual material handling jobs have a variety of different work components that make it difficult to apply any of the three methods in a pure sense. Workers are often required to lift, carry, hold, and lower loads that vary in location and weight throughout the workday. Typical of this are the many warehousing operations currently done manually in the United States. These jobs have so many different tasks components that it is impractical to analyze each task, and even if this could be done, there is currently no agreed method of aggregating task indices of risk into a job index of risk. Workers are also increasingly being asked to rotate between several different jobs with one of the jobs having a large manual materials handling component. In addition, ten and twelve hour work shifts have become common at many work sites.

The variety of different work tasks being done by typical industrial workers presented a problem for the task oriented models presented in this chapter. Ergonomics practitioners are often confused by conflicting recommendations provided by different models and even by the same model for different tasks performed by a worker within a workday. It is the authors' opinion that future modeling efforts should and will concentrate on providing insight into the musculoskeletal risks of jobs and careers, instead of tasks. Whether this is done by combining the task level approaches documented in this chapter into a composite measure, or through an entirely different method is not entirely clear at this time. However, the greatest need in preventing manual materials handling injuries is understanding the cumulative effects of work tasks done over days, years, and even a work career. 


\section{References}

Aberg, U., Elgstrand, K., Magnus, P., and Lindholm, A., 1968, Analysis of components and prediction of energy expenditure in manual tasks, The International Journal of Production Research, 6, 189-196.

Aghazadeh, F., 1974, Lifting Capacity as a Function of Operator and Task Variables, Unpublished MS thesis, Texas Tech University, Lubbock, TX.

Aghazadeh, F., 1983, Simulated Dynamic Lifting Strength Models for Manual Lifting, Unpublished doctoral dissertation, Texas Tech University, Lubbock, TX.

Aghazadeh, F., and Ayoub, M. M., 1985, A comparison of dynamic- and static-strength models for prediction of lifting capacity, Ergonomics, 28(10), 1409-1417.

Anderson, C. K., 1983, A Biomechanical Model of the Lumbosacral Joint for Lifting Activities, Unpublished doctoral dissertation, The University of Michigan, Ann Arbor, Michigan.

Aquilano, N. J., 1968, A physiological evaluation of time standards for strenuous work as set by stopwatch time study and two predetermined motion time data systems, Journal of Industrial Engineering, 19, 425-432.

Asfour, S. S., 1980, Energy Cost Prediction Models for Manual Lifting and Lowering Tasks, Unpublished doctoral dissertation, Texas Tech University, Lubbock, TX.

Asfour, S. S., Ayoub, M. M., and Genaidy, A. M., 1984a, A psychophysical study of the effect of task variables on lifting and lowering tasks, Journal of Human Ergology, 13, 3-14.

Asfour, S. S., Ayoub, M. M., and Mital, A., 1984b, Effects of an endurance and strength training programme on the lifting capability of males. Ergonomics, 27, 435-442.

Asfour, S. S., Ayoub, M. M., and Genaidy, A. M., 1985, Computer models for the prediction of lifting and lowering capacity, in IEEE 1985 Proceedings of International Conference on Cybernetics and Society, Tucson, AZ: IEEE Systems, Man, and Cybernetics Society, pp. 1092-1096.

Asfour, S. S., Ayoub, M. M., and Genaidy, A. M., 1986a, A data base of physiological responses to manual lowering, in Karwowski, W. (Ed.), Trends in Ergonomics/Human Factors III, Amsterdam: Elsevier, pp. 811-818.

Asfour, S. S., Ayoub, M. M., Genaidy, A. M., and Khalil, T. M., 1986b, A data base of physiological responses to manual lifting, in Karwowski, W. (Ed.), Trends in Ergonomics/ Human Factors III, Amsterdam: Elsevier, pp. 801-809.

Astrand, P. O., and Rodahl, K., 1986, Textbook of Work Physiology, 3rd edn., New York: McGraw-Hill.

Ayoub, M. M., and El-Bassoussi, M. M., 1976, Dynamic biomechanical model for sagittal lifting activities. Proceedings of the 6th Congress of International Ergonomics Association, pp. 355-359.

Ayoub, M. M., and Mital, A., 1989, Manual Materials Handling, London: Taylor \& Francis.

Ayoub, M. M., Bethea, N. J., Deivanayagam, S., Asfour, S. S., Bakken, G. M., Liles, D., et al., 1978a, Determination and Modeling of Lifting Capacity, Final Report HEW [NIOSH] 5R010H-00545-02, Lubbock, TX: Texas Tech University.

Ayoub, M. M., Dryden, R. D., McDaniel, J. W., Knipfer, R. E., and Aghazadeh, F., 1978b, Modeling of lifting capacity as a function of operator and task variables, in Safety in Manual Materials Handling, DHEW (NIOSH) Publication No. 78-185, Department of Health Education and Welfare, National Institute for Occupational Safety and Health, Cincinnati, $\mathrm{OH}$.

Ayoub, M. M., Mital, A., Asfour, S. S., and Bethea, N. J., 1980, Review, evaluation, and comparison of models for predicting lifting capacity, Human Factors, 22, 257-269.

Ayoub, M. M., Bethea, N. J., Bobo, M., Burford, C. L., Caddel, K., Intaranont, K., et al., 1981, Mining in Low Coal, Vol. 1, Biomechanics and Work Physiology, Final Report, US Bureau of Mines, Contract No. H03087022.

Ayoub, M. M., Selan, J. L., and Jiang, B. C., 1983, A Mini-Guide for Lifting, Lubbock, TX: Department of Industrial Engineering, Texas Tech University. 
Bean, J. C., Chaffin, D. B., and Schultz, A. B., 1988, Biomechanical model calculation of muscle forces: a double linear programming method, Journal of Biomechanics, 21, 59-66.

Borg, G. A. V., 1962, Physical Performance and Perceived Exertion, Lund: Gleerup.

Bringham, C. J., and Garg, A., 1983, The Role of Biomechanical Job Evaluation in the Reduction of Overexertion Injuries: A Case Study, Paper at the 23rd Annual American Industrial Hygiene Association Conference, Philadelphia, PA.

Chaffin, D. B., 1967, The Development of a Prediction Model for the Metabolic Energy Expended During Arm Activity, Unpublished doctoral dissertation, University of Michigan, Ann Arbor, MI.

Chaffin, D. B., and Andersson, G. B. J., 1991, Occupational Biomechanics, 2nd edn. New York: John Wiley \& Sons.

Chaffin, D. B., and Park, K. S., 1973, A longitudinal study of low-back pain as associated with occupational weight lifting factors, American Industrial Hygiene Association Journal, 31, 513-525.

Chaffin, D. B., Redfern, M. S., Erig, M., and Goldstein, S. A., 1990, Lumbar muscle size and locations from CT scans of 96 women of age 40 to 63 years, Clinical Biomechanics, 5, 9-16.

Chen, H. C., 1988, Biomechanical Stresses During Asymmetric Lifting - A Dynamic Three-Dimensional Approach, Unpublished doctoral dissertation, Texas Tech University, Lubbock, TX.

Cholewicki, J., and McGill, S. M., 1996, Mechanical stability on the in vivo lumbar spine: implications for injury and chronic low back pain. Clinical Biomechanics, 11(1), 1-15.

Clauser, C. W., McConville, J. T., and Young, J. W., 1969, Weight, Volume and Center of Mass of Segments of the Human Body, AMRL-TR-69-70, Aerospace Medical Research Laboratories, $\mathrm{OH}$.

Crowminshield, R. D., and Brand, R. A., 1981, A physiologically based criterion of muscle force prediction in locomotion, Journal of Biomechanics, 14(11), 793-801.

Davis, K. G., Marras, W. S., and Granata, K. P., 1997, The effect of task asymmetry and number of hands on spinal loading. Proceedings of the Human Factors and Ergonomics Society 41st Annual Meeting, Albuquerque, NM.

Deivanayagam, S., and Ayoub, M. M., 1979, Prediction of endurance time for alternating workload tasks. Ergonomics, 22, 279-290.

Dempster, W. T., 1955, Space Requirements of the Seated Operator, WADC-TR-55-159, Aerospace Medical Research Laboratories, $\mathrm{OH}$.

Dryden, R. D., 1973, A Predictive Model for the Maximum Permissible Weight of Lift from Knuckle to Shoulder Height, Unpublished doctoral dissertation, Texas Tech University, Lubbock, TX.

Dumas, G. A., Poulin, M. J., Roy, B., Gagnon, M., and Jovanovic, M., 1988, A three-dimensional digitization method to measure trunk muscle line of action, Spine, 13(5), 532-541.

Durnin, J. V. G. A., and Passmore, R., 1967, Energy, Work and Leisure, London: Heinemann Educational.

Eisler, H., 1962, Subjective scale of force for a large muscle group. Journal of Experimental Psychology, 64(3), 253-257.

Frederick, W. S., 1959, Human energy in manual lifting, Modern Materials Handling, 14, 74-76.

Freivalds, A., Chaffin, D. B., Garg, A., and Lee, K. S., 1984, A dynamic biomechanical evaluation of lifting maximum acceptable loads, Journal of Biomechanics, 17, 251-262.

Garg, A., 1976, A Metabolic Rate Prediction Model for Manual Materials Handling Jobs, Unpublished doctoral dissertation, University of Michigan, Ann Arbor, MI.

Garg, A., and Ayoub, M. M., 1980, What criteria exist for determining how much load can be lifted safely? Human Factors, 22, 475-486.

Garg, A., Chaffin, D. B., and Herrin, G. D., 1978, Prediction of metabolic rates for manual materials handling jobs, American Industrial Hygiene Association Journal, 39, 661-674.

Garg, A. Chaffin, D. B., and Freivalds, A., 1982, Biomechanical stresses from manual load lifting: a static vs dynamic evaluation, Transactions of the American Institute of Industrial Engineers, 14, $272-281$. 
Genaidy, A. M., and Asfour, S. S., 1987, Review and evaluation of physiological cost prediction models for manual materials handling, Human Factors, 29(4), 465-476.

Genaidy, A. M., Asfour, S. S., Khalil, T. M., and Waly, S. M., 1985a, Physiologic issues in manual materials handling, in Eberts, R., and Eberts, C. G. (Eds.), Trends in Ergonomics/ Human Factor II, Amsterdam: Elsevier, pp. 571-576.

Genaidy, A. M., Asfour, S. S., and Muthuswamy, S., 1985b, Modeling of physiologic responses to manual work: a systems approach, in IEEE Proceedings of the International Conference on Cybernetics and Society, Tucson, AZ: IEEE Systems, Man, and Cybernetics Society, pp. 1107-1110.

Genaidy, A. M., Asfour, S. S., Mital, A., and Trita, M., 1988, Psychophysical capacity modeling in frequent manual materials handling activities, Human Factors, 30(3), 319-337.

Granata, K. P., and Marras, W. S., 1996, Biomechanical models in ergonomics, in Bhattacharya, A., and McGlothlin, J. D. (Eds.), Occupational Ergonomics - Theory and Application, New York, NY: Marcel Dekker.

Hamilton, B. J., and Chase, R. B., 1969, A work physiology study of the relative effects of pace and weight in a carton handling task, Transactions of the American Institute of Industrial Engineers, 1, 106-111.

Han, J. S., Ahn, J. Y., Goel, V. K., Takeuchi, R., and McGowan, D., 1992, CT-based geometric data of human spine musculature. Part 1. Japanese patients with chronic low back pain, Journal of Spinal Disorders, 5(4), 448-458.

Herrin, G. D., Jariedi, M., and Anderson, C. K., 1986, Prediction of overexertion injuries using biomechanical and psychophysical models, American Industrial Hygiene Association Journal, 47, 322-330.

Hughes, R. E., 1991, Empirical Evaluation of Optimization-Based Lumbar Muscle Force Prediction Models, Unpublished doctoral dissertation, University of Michigan, Ann Arbor, MI.

Jiang, B., 1984, Psychophysical Capacity Modeling of Individual and Combined Manual Materials Handling Activities, Unpublished doctoral dissertation, Texas Tech University, Lubbock, TX.

Jiang, B., Smith, J. L., and Ayoub, M. M., 1986, Psychophysical modelling for combined manual materials-handling activities, Ergonomics, 29(10), 1173-1190.

Kamon, E., Kiser, D., and Pytel, J. L., 1982, Dynamic and static lifting capacity and muscular strength of steelmill workers, American Industrial Hygiene Association Journal, 43(11), 853-857.

Karwowski, W., and Ayoub, M. M., 1984a, Effect of frequency on the maximum acceptable weight of lift, in Mital, A. (Ed.), Trends in Ergonomics/Human Factors I, Amsterdam: Elsevier, pp. 167-172.

Karwowski, W., and Ayoub, M. M., 1984b, Fuzzy modeling of stresses in manual lifting tasks, Ergonomics, 27, 641-649.

Kee, D., and Chung, M. K., 1996, Comparison of prediction models for the compression force on the lumbosacral disc, Ergonomics, 39(12), 1419-1430.

Kim, H., 1990, Model for Combined Ergonomic Approaches in Manual Materials Handling Tasks, Unpublished doctoral dissertation, Texas Tech University, Lubbock, TX.

Knipfer, R. E., 1974, Predictive Models for the Maximum Acceptable Weight of Lift, Unpublished doctoral dissertation, Texas Tech University, Lubbock, TX.

Ladin, Z., Murthy, K. R., and Deluca, C. J., 1989, Mechanical recruitment of low-back muscles: theoretical predictions and experimental validation, Spine, 14(9), 927-938.

Leamon, T. B., 1994, Research to reality: a critical review of the validity of various criteria for the prevention of occupationally induced low back pain, Ergonomics, 37(12), 1959-1974.

Legg, S. J., and Myles, W. S., 1981, Maximum acceptable repetitive lifting workloads for an 8-hour work day using psychophysical and subjective rating methods, Ergonomics, 24(12), 907-916.

Leskinen, T. P. J., Stalhammer, H. R., Kuorinka, I. A. A., and Troup, J. D. G., 1983, The effect of inertial factors on spinal stress when lifting, Engineering in Medicine, 12, 87-89.

Liou, Y. H., and Morrissey, S. J., 1985, Predicting male and female physiological costs of load carriage, in Eberts, R., and Eberts, C. G. (Eds.), Trends in Ergonomics/Human Factors II, Amsterdam: Elsevier, pp. 633-639. 
Macintosh, J. E., and Bogduk, N., 1986, The biomechanics of the lumbar multifidus. Clinical Biomechanics, 1(4), 205-213.

Mairiaux, P. H., and Malchaire, J., 1988, Relation between intra-abdominal pressure and lumbar stress: effect of trunk posture, Ergonomics, 31(9), 1331-1342.

Marras, W., and Sommerich, C., 1991a, A three dimensional motion model of loads on the lumbar spine, I: model structure, Human Factors, 33, 123-137.

Marras, W., and Sommerich, C., 1991b, A three dimensional motion model of loads on the lumbar spine, II: model validation, Human Factors, 33, 139-149.

Marras, W. S., Lavender, S. A., Leurgans, S. E., Rajulu, S. L., Allread, W. G., Fathallah, F. A., and Ferguson, S. A., 1993, The role of dynamic three-dimensional trunk motion in occupationally-related low back disorders: the effects of workplace factors, trunk position and trunk motion characteristics on risk of injury. Spine, 18, 617-628.

Marras, W. S., Lavender, S. A., Leurgans, S. E., Fathallah, F. A., Ferguson, S. A., Allread, W. G., and Rajulu, S. L., 1995, Biomechanical risk factors for occupationally-related low back disorders, Ergonomics, 28, 377-410.

Marras, W. S., Davis, K. G., Kirking, B. C., and Granata, K. P., 1997, Spine loading and trunk kinematic changes during team lifting, Proceedings of the Human Factors and Ergonomics Society 41st Annual Meeting, Albuquerque, NM.

McConville, J. T., and Hertzberg, H. T., 1966, A Study of One Hand Lifting, Wright-Patterson AFB, Ohio, Aerospace Medical Research Laboratory, Technical Report, AMRL-TR-66-17.

McDaniel, J. W., 1972, Prediction of Acceptable Lift Capability, Unpublished doctoral dissertation, Texas Tech University, Lubbock, TX.

McGill, S. M., 1992, A myoelectrically based dynamic three dimensional model to predict loads on lumbar spine tissues during lateral bending, Journal of Biomechanics, 25, 395-414.

McGill, S. M., and Norman, R. W., 1986, Partitioning of the L4-L5 dynamic moment into disc, ligamentous, and muscular components during lifting. Spine, 11(7), 666-678.

McGill, S. M., Patt, N., and Norman, R. W., 1988, Measurement of the trunk musculature of active males using CT scan radiography: Implication for force and moment generating capacity about the L4/L5 joint, Journal of Biomechanics, 21(4), 329-341.

McMulkin, M. L., 1996, Investigation and Empirical Evaluation of Inputs to Optimization-Based Biomechanical Trunk Models, Unpublished doctoral dissertation, Virginia Polytechnic Institute and State University, Blacksburg, VA.

Mital, A., 1983a, The psychophysical approach in manual lifting-a verification study. Human Factors, 25, 485-491.

Mital, A., 1983b, Prediction of maximum weights of lift acceptable to male and female industrial workers. Journal of Occupational Accidents, 5, 223-231.

Mital, A., 1983c, Generalised model structure for evaluating/designing manual materials handling jobs. International Journal of Production Research, 21, 401-412.

Mital, A., 1984, Comprehensive maximum acceptable weight of lift database for regular 8-hour workshifts. Ergonomics, 27, 1127-1138.

Mital, A., 1985, Models for predicting maximum acceptable weight of lift and heart rate and oxygen uptake at that weight, Journal of Occupational Accidents, 7, 75-82.

Mital, A., and Asfour, S. S., 1983, Material handling capacity of workers, Material Flow, 1, 89-100.

Mital, A., and Ayoub, M. M., 1980, Modeling of isometric strength and lifting capacity, Human Factors, 22, 285-290.

Mital, A., and Kromodihardjo, S., 1986, Kinetic analysis of manual lifting activities: Part II - Biomechanical analysis of task variables. International Journal of Industrial Ergonomics, 1, 91-101.

Mital, A., Shell, R. L., Mital, C., Sanghavi, N., and Ramanann, S., 1984, Acceptable Weight of Lift for Extended Workshifts, Tech. Report Grant No. 1-R01-OH-01429-01 \& 2, Cincinnati, OH: NIOSH. 
Mital, A., Nicholson, A. S., and Ayoub, M. M., 1997, A Guide to Manual Materials Handling, London: Taylor \& Francis.

Morrissey, S. J., and Liou, Y. H., 1984a, Development of models for predicting metabolic costs of carrying loads with a range of container sizes, in Mital, A. (Ed.), Trends in Ergonomics/ Human Factor I, Amsterdam: Elsevier, pp. 173-178.

Morrissey, S. J., and Liou, Y. H., 1984b, Metabolic costs of load carriage with different container sizes. Ergonomics, 27, 847-853.

Morrissey, S. J., and Liou, Y. H., 1984c, Predicting the metabolic costs of carrying loads in erect and stooped task postures, in Mital, A. (Ed.), Trends in Ergonomics/Human Factors I, Amsterdam: Elsevier, pp. 179-184.

NASA, 1978, Anthropometric Source Book, NASA Reference Publication No. 1024, National Aeronautics and Space Administration.

NIOSH, 1981, Work Practices Guide for Manual Lifting, NIOSH Technical Report No. 81-122, US Department of Health and Human Services, National Institute for Occupational Safety and Health, Cincinnati, $\mathrm{OH}$.

NIOSH, 1994, Applications Manual for the Revised NIOSH Lifting Equation, NIOSH Technical Report No. 94-110, US Department of Health and Human Services, National Institute for Occupational Safety and Health.

Nussbaum, M. A., and Chaffin, D. B., 1996, Evaluation of artificial neural network modelling to predict torso muscle activity, Ergonomics, 39(12), 1431-1444.

Ozkaya, N., and Nordin, M., 1991, Fundamentals of Biomechanics: Equilibrium, Motion, and Deformation, New York: Van Nostrand Reinhold.

Poulsen, E., 1970, Prediction of maximum loads in lifting from measurements of back muscle strength, Progressive Physical Therapy, 1, 146-149.

Pytel, J. L., and Kamon, E., 1981, Dynamic strength test as a predictor for maximal and acceptable lifting, Ergonomics, 24(9), 663-672.

Schultz, A. B., Haderspeck, K., Warwick, D., and Portillo, D., 1983, Use of lumbar trunk muscles in isometric performance of mechanically complex standing tasks, Journal of Orthopaedic Research, $1,77-91$.

Snook, S. H., 1976, Psychophysiological indices - what people will do. Report on International Symposium: Safety in Manual Materials Handling, State University of New York at Buffalo: NIOSH, pp. 63-67.

Snook, S. H., 1978, The design of manual handling tasks. Ergonomics, 21, 963-985.

Snook, S. H., and Ciriello, V. M., 1974, Maximum weights and workloads acceptable to female workers, Journal of Occupational Medicine, 16, 527-534.

Snook, S. H., Irvine, C. H., and Bass, S. F., 1970, Maximum weights and workloads acceptable to male industrial workers, American Industrial Hygiene Association Journal, 31, 579-586.

Stevens, S. S., 1975, Psychophysics: Introduction to its Perceptual, Neural, Social Prospects, Wiley.

Taboun, S. M., 1986, Models of Individual and Combined Materials Handling Tasks, Unpublished doctoral dissertation. University of Windsor, Windsor, Ontario, Canada.

Tracy, M. F., Gibson, M. J., Szypryt, E. P., Rutherford, A., and Corlett, E. N., 1989, The geometry of the muscles of the lumbar spine determined by magnetic resonance imaging, Spine, 14(2), 186-193.

Williams, M., and Lissner, H. R., 1977, Biomechanics of Human Motion, 2nd edn. (B. Le Veau, Ed.), Philadelphia: Saunders.

Winter, D. A., 1990, Biomechanics and Motor Control of Human Behavior, 2nd edn. New York: John Wiley \& Sons. 